\title{
Social Cohesion and Civil Law: Marriage, Divorce and Religious Courts
}

\section{Report of a Research Study funded by the AHRC}

\author{
by
}

Gillian Douglas, Norman Doe, Sophie Gilliat-Ray, Russell Sandberg and Asma Khan

Cardiff University

June 2011

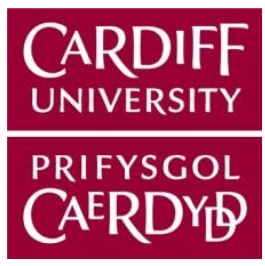


published in Great Britain in 2011 by:

Cardiff Law School

Cardiff University

Museum Avenue

Cardiff CF10 3AX

http://www.law.cf.ac.uk/clr/research/cohesion

(C) Gillian Douglas, Norman Doe, Sophie Gilliat-Ray, Russell Sandberg, Asma Khan 2011

Gillian Douglas is Professor of Law at Cardiff Law School, Norman Doe is Professor of Law and Director of the Centre for Law and Religion, Cardiff Law School, Sophie Gilliat-Ray is Senior Lecturer in the School of History, Archaeology and Religion and Director of the Centre for the Study of Islam in the UK, Russell Sandberg is a Lecturer in Law at Cardiff Law School and Asma Khan is a former Research Associate at Cardiff University

All rights reserved: no part of this publication may be reproduced, stored in a retrieval system, or transmitted in any form or by any means, electronic, mechanical, photocopying, recording or otherwise without the prior written permission of the authors.

\section{Acknowledgements}

The authors wish to acknowledge the support of the Arts and Humanities Research Council for providing funding to undertake this study within the AHRC/ESRC Religion and Society Programme and to thank Professor Linda Woodhead, University of Lancaster, Director of the Programme and her team for their advice and assistance. We also wish to thank the members of the three religious tribunals who agreed to participate in the study, without whose generous commitment of time, advice and encouragement we would not have been able to complete our work. 


\section{Contents}

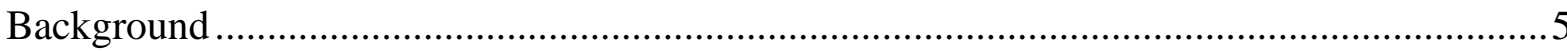

Part One: The Regulation of Religion and Religious Law in England and Wales ...........7

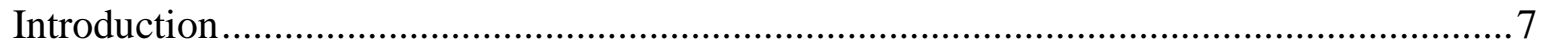

The Regulation of Religion in England and Wales ...................................................

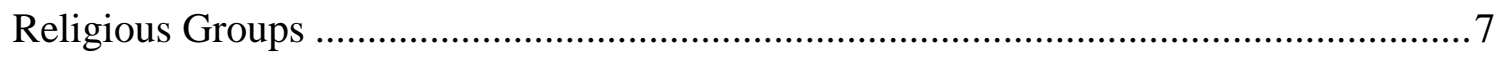

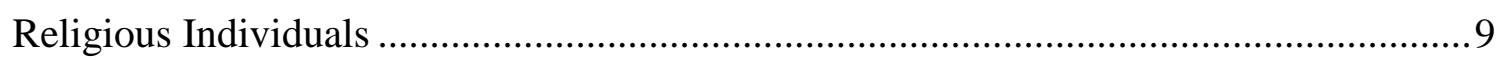

The Recognition of Religious Law in England and Wales.......................................... 10

The Recognition of Religious Family Law in England and Wales .................................. 12

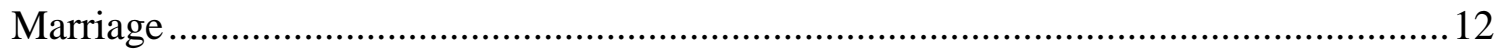

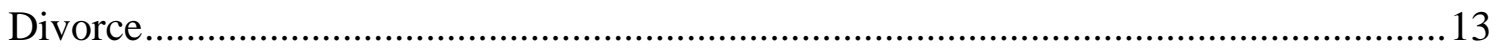

The Recognition of Religious Courts in England and Wales .......................................... 15

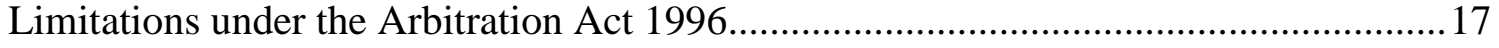

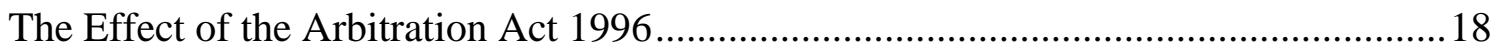

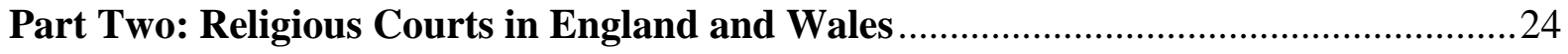

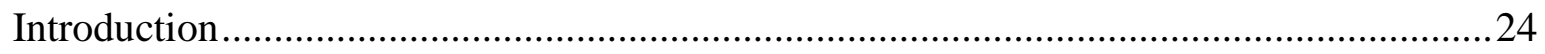

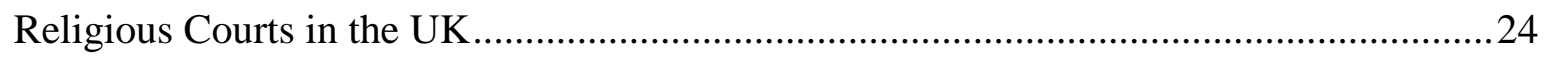

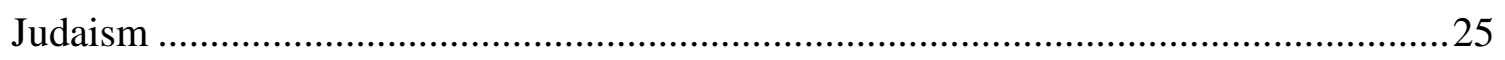

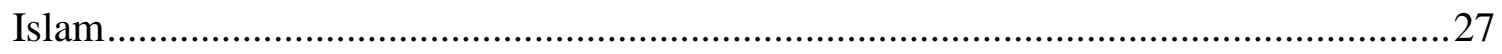

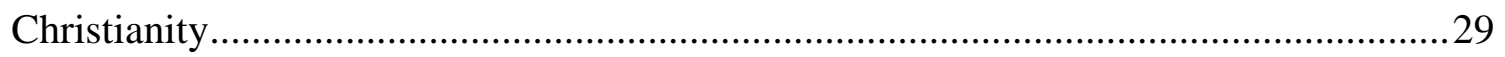

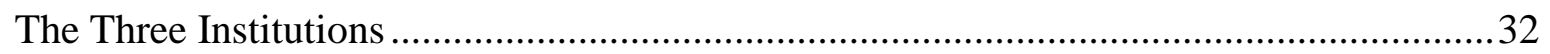

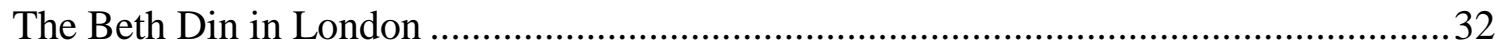

The Shariah Council of the Birmingham Central Mosque ...............................................35

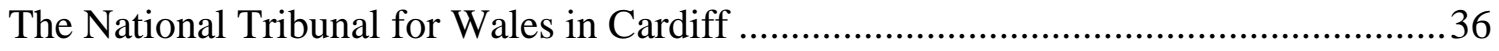

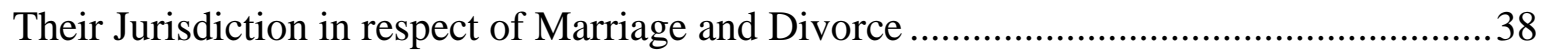

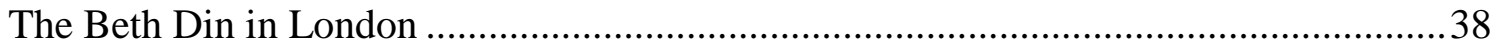

The Shariah Council of the Birmingham Central Mosque ............................................ 39 
The National Tribunal for Wales in Cardiff .

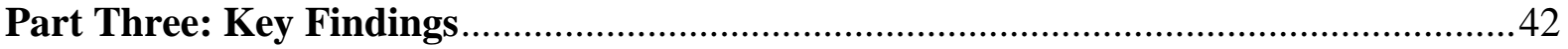

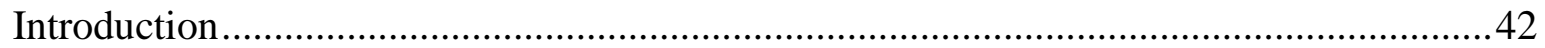

The Tribunals, their Structure and Sources of Authority ................................................. 42

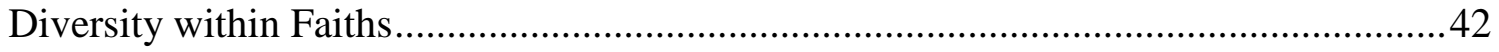

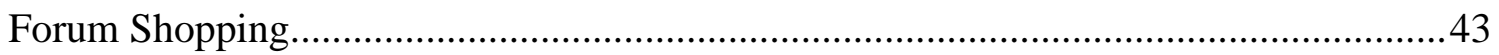

Flexibility in use of Sources of Law and Authority .................................................. 43

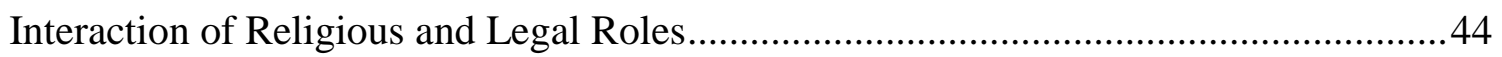

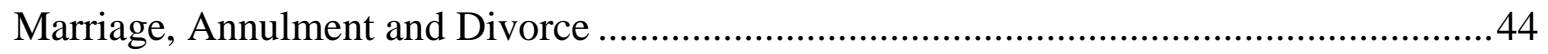

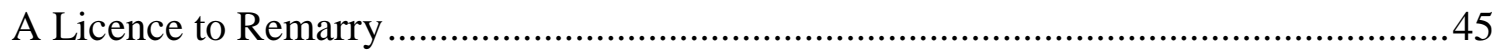

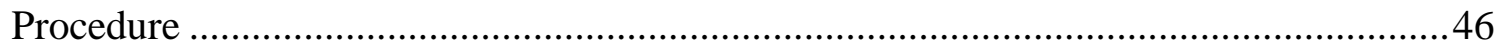

Limited Role in Relation to the 'Ancillaries' ............................................................ 47

The Relationship between the Tribunals and Societal/Civil Law Expectations .................47

Interaction between Civil and Religious Law .......................................................... 47

The Place of the Religious Tribunal within the wider Society ......................................48

Providing a Service for the Faith Community ........................................................... 48 


\section{Background}

This Cardiff University study of religious courts and tribunals across the UK has been funded by the AHRC/ESRC Religion and Society Programme. The project, 'Social Cohesion and Civil Law: Marriage, Divorce and Religious Courts', explores how religious law functions alongside civil law in England and Wales.

The context, though not the catalyst, for our study, is the lecture given by the Archbishop of Canterbury in 2008 on the relationship between religious law - primarily though not exclusively Islamic - and civil law in England and Wales. ${ }^{1}$ In that lecture, Rowan Williams sought to bring to a higher level of public debate than the tabloid press to the question of 'what it is like to live under more than one (legal) jurisdiction' and how (and how far) the civil law of the land should recognise or accommodate a legal pluralism based on religious adherence.

Part - perhaps much - of the public outcry which greeted the Archbishop's lecture in 2008 reflected a lack of knowledge of how religious courts already operate in this country. Mediahyped fears over the operation of shariah courts were matched with prejudiced comments about the privileging of Jewish courts which have indeed operated in this country for over a hundred years. And no one mentioned that the Roman Catholic Church has handed down decrees of nullity of marriage throughout its history. So our project explores how religious law already functions alongside civil law in England and Wales. The simple aim of our study was:

'to collect information on the role and practice of religious courts in England and Wales in order to contribute to debate concerning the extent to which English law should accommodate religious legal systems'.

Our more detailed objectives were to:

1. Survey the existence, organisational structure and legal status of religious courts and tribunals across the UK in with detailed examination of three selected institutions (the Catholic National Tribunal for Wales in Cardiff; the Jewish London Beth Din, Family Division; and the Shariah Council of the Birmingham Central Mosque);

\footnotetext{
${ }^{1}$ R Williams, 'Civil and Religious Law in England: A Religious Perspective' 7 February 2008, reprinted in (2008) 10 Ecclesiastical Law Journal 262.
} 
2. Explore the jurisdiction each of these tribunals has in relation to marriage, divorce and remarriage and how this is administered and enforced, by reference to the decisions made by the bodies and the experience and views of court personnel;

3. Evaluate whether this jurisdiction (and its use) is compatible with civil law in the UK and anticipate future trends;

4. Develop a dialogue with the studied institutions in order to pave the way for further interdisciplinary research; and finally,

5. Contribute to wider national and international discussion as to the relationship between religious and civil law, through the production of outputs disseminating the research among a range of specialist and non-specialist audiences.

This document brings together three documents which have previously been published on our website: http://www.law.cf.ac.uk/clr/research/cohesion The first part examines the legal status of religious courts and tribunals under English law. The second part examines the existence of religious courts in general in the UK and the organisational structure of the selected Jewish, Christian and Islamic institutions in particular. The third part sets out the key findings from the research.

Professor Gillian Douglas

Professor Norman Doe

Dr Sophie Gilliat-Ray

Dr Russell Sandberg

Asma Khan 


\section{Part One: The Regulation of Religion and Religious Law in England and Wales}

\section{Introduction}

Part one of this Commentary falls into four sections. The first section provides a general overview of how English law regulates religion. The second section discusses how religious law is recognised under English law whilst the third section focuses upon the recognition of religious family law, the object of our study. The fourth section examines how religious courts are recognised under English law, with particular reference to the Arbitration Act 1996.

\section{The Regulation of Religion in England and Wales}

Unlike many European countries, ${ }^{2}$ English law does not include detailed registration schemes for religious groups. However, this does not mean that religion is not regulated. Although registration is not compulsory under English law, a multitude of overlapping laws have been enacted to recognise and regulate both religious groups and religious individuals enabling them to benefit from legal and fiscal advantages.

\section{Religious Groups}

The constitutional position of religion differs in the divergent nations of the United Kingdom. ${ }^{3}$ Formerly in all four nations there were established churches. However, legislation disestablishing the national church has been enacted in respect of Ireland and Wales. ${ }^{4}$ There are two different established churches in England and Scotland respectively: the Church of England is an Episcopal Anglican Church; the Church of Scotland is Presbyterian.

This commentary focuses upon the law of England and Wales. It will focus upon the legal status of religious groups other than the Church of England. ${ }^{5}$ By dint of its established

\footnotetext{
${ }^{2}$ See L Friedner (ed), Churches and Other Religious Organisations as Legal Persons (Peeters, 2007).

3 The following draws upon M Hill, R Sandberg and N Doe, Religion Law: United Kingdom (Kluwer Law International, International Encyclopaedia of Laws Series 2010) para 107 et seq.

${ }^{4}$ Irish Church Act 1869; Welsh Church Act 1914.

${ }^{5}$ On which see M Hill, Ecclesiastical Law ( $3^{\text {rd }}$ edition, Oxford University Press, 2007) and N Doe, The Legal Framework of the Church of England (Oxford University Press 1996).
} 
status, the law of the Church of England is part of the general law of England. ${ }^{6}$ Pieces of Church law - called Measures - are created by a religious body (the General Synod of the Church of England) but are then considered by the Ecclesiastical Committee of Parliament. Once given Royal Assent they have the same effect as an Act of Parliament. ${ }^{7}$ The legal status of the disestablished Church in Wales also differs from other religious groups: although it shares many features with all other religious groups, it continues to share some features with the Church of England, especially in relation to the regulation of rites of passage. $^{8}$

Since toleration, religious groups other than the Church of England have been lawful and allowed to practise their religion. ${ }^{9}$ There are several legal mechanisms which require religious groups to register to acquire a certain legal status, most notably in the form of registration as a place of religious worship ${ }^{10}$ and for the solemnisation of marriage. ${ }^{11}$ Religious groups may seek to register as a charity for the advancement of religion. ${ }^{12}$ Such registration typically enables religious groups to achieve fiscal advantages.

Regardless of registration status, all religious groups are usually treated as voluntary associations. $^{13}$ The relationship of members as between themselves is governed by quasicontract and the organisations are treated as a matter of law as members of clubs or unincorporated associations. These exist where two or more people are voluntarily bound together for common purposes and undertake mutual duties and obligations. Unincorporated associations have no legal personality distinct from their members (unlike a corporation): they cannot sue or be sued and cannot hold property (though institutions within them may be legal owners of property if they have the status of corporations or trustees). Religious voluntary associations seeking legal personality can form as a limited company.

\footnotetext{
${ }^{6}$ Mackonochie v Lord Penzance (1881) 6 App Cas 424.

${ }^{7}$ Church of England Assembly (Powers) Act 1919, s1(5). See $R v$ Archbishops of Canterbury and York Ex parte Williamson (1994) The Times 9 March.

${ }^{8}$ See N Doe, The Law of the Church in Wales (University of Wales Press, 2002).

${ }^{9}$ See R Sandberg, Law and Religion (Cambridge University Press, 2011) chapter 4.

${ }^{10}$ Places of Worship Registration Act 1855.

${ }^{11}$ Marriage Act 1949, s.41.

${ }^{12}$ Charities Act 2006.

${ }^{13}$ As explained above, the Church of England (and to a lesser extent the Church in Wales) also have some recognition in public law
} 
These private law facilities are occasionally buttressed by legislation. Religious groups are occasionally recognised by statute. Examples include the Trustee Appointment Act 1850 which simplified the transfer of places of religious worship from one group of trustees to another and the Sharing of Church Buildings Act 1969 which facilitates ecumenical sharing arrangements as well as more specific pieces of legislation such as the Methodist Church Act 1976 and United Reformed Church Act 2000. Statutory recognition does not give a religious body legal personality.

The fact that religious groups are treated legally as voluntary associations means that the rules and structures of voluntary associations are binding on assenting members. This contractual bond may be styled the doctrine of 'consensual compact'. ${ }^{14}$ As Lord Kingsdown acknowledged in Long $v$ Bishop of Capetown' ${ }^{15}$, members 'may adopt rules for enforcing discipline within their body which will be binding on those who, expressly or by implication, have assented to them.' It is also often understood that these rules and structures are also binding on the association itself. ${ }^{16}$

\section{Religious Individuals}

With respect to religious individuals, the traditional legal position has been that everyone has the right to do whatever they like unless restrained by the law. ${ }^{17}$ Religious laws and practices are free to operate where the law of the State is silent. This 'negative' protection of religious freedom has been bolstered in recent years by a number of laws giving 'positive' legal rights, most notably the Human Rights Act 1998 and new laws prohibiting discrimination on grounds of religion or belief. The Human Rights Act 1998 gave effect in domestic law to the rights and freedoms guaranteed under the European Convention on Human Rights (ECHR). Convention rights (including freedom of religion under Article 9) are now part of domestic law, enforceable in domestic courts. ${ }^{18}$ The Employment Equality (Religion or Belief) Regulations 2003 and the Equality Act 2006 prohibited for the first time discrimination on

\footnotetext{
${ }^{14}$ The doctrine is most fully elucidated in the Australian case of Scandrett v Dowling [1992] 27 NSWLR 483 discussed below.

15 (1863) 1 Moore NS Cases 461.

${ }^{16}$ For example in Davies $v$ Presbyterian Church of Wales [1986] 1 WLR 323 Lord Templemen held that 'The law imposes on the church a duty not to deprive a pastor of his office which carries a stipend, save in accordance with the procedures set forth in [its] book of rules'.

${ }_{17}^{17}$ Donaldson MR, AGv Guardian Newspapers Ltd (No 2) [1990] 1 AC 109.

${ }^{18}$ For analysis see, e.g., M Hill and R Sandberg, 'Is Nothing Sacred? Clashing Symbols in a Secular World' [2007] Public Law 488-506.
} 
grounds of religion or belief in employment and the provision of goods and services. ${ }^{19}$ These discrimination law provisions are now to be found in the Equality Act 2010. ${ }^{20}$

\section{The Recognition of Religious Law in England and Wales}

The courts of the State are generally reluctant to become involved in adjudicating internal disputes within religious groups concerning religious law. ${ }^{21}$ An example of this may be found in the High Court decision in Blake v Associated Newspapers ${ }^{22}$ which concerned the question of whether Blake was a proper 'Bishop'. Blake, a former Church of England cleric who founded 'The Society for Independent Christian Ministry', was suing the defendant for libel for calling him a 'self styled bishop' and an 'imitation bishop'. Gray J held that the issue was non-justiciable since 'many of the issues [fell] within the territory which the courts, by selfdenying ordinance, will not enter'. ${ }^{23}$ Answering such questions 'would involve a detailed and painstaking examination of questions of doctrine, theology and ecclesiology combining an assessment of history and a full understanding of contemporary and emergent theology and ecumenism? ${ }^{24}$

This discernible reticence on the part of the English courts to become involved in adjudicating disputes within churches may be elevated to a principle of non-interference. In His Holiness Sant Baba Jeet Singh Maharaj v Eastern Media Group Ltd ${ }^{25}$ Eady J held that 'the well-known principle of English law to the effect that the courts will not attempt to rule upon doctrinal issues or intervene in the regulation or governance of religious groups' constituted a self-denying ordinance, applied as a matter of public policy'. ${ }^{26}$ He held that 'such disputes as arise between the followers of any given religious faith are often likely to involve doctrines or beliefs which do not readily lend themselves to the sort of resolution which is the normal function of a judicial tribunal'. Eady $\mathrm{J}$ was by no means the first judge to recognise this principle. As Simon Brown J stated in 1992, courts are 'hardly in a position to regulate' religious functions: 'The court must inevitably be wary of entering so self-evidently

\footnotetext{
${ }^{19}$ For analysis see R Sandberg, Law and Religion (Cambridge University Press, 2011) chapter 5.

${ }^{20}$ For analysis see ibid chapter 6.

${ }^{21}$ For discussion of the usefulness of the term 'religious law' see ibid chapter 9 and the essays in A Huxley (ed) Religion, Law and Tradition: Comparative Studies in Religious Law (Routledge, 2002).

22 [2003] EWHC 1960.

${ }^{23}$ Para 24.

${ }^{24}$ Para 21.

${ }^{25}$ [2010] EWHC (QB) 1294

${ }^{26}$ Para 5.
} 
sensitive an area, straying across the well-recognised divide between church and state'. ${ }^{27}$ Munby J in 2002 held that this meant that 'the starting point of the law is an essentially agnostic view of religious beliefs and a tolerant indulgence to religious and cultural diversity'. ${ }^{28}$

This rule was recently asserted by Lord Hope in the Supreme Court in $R$ (on the application of E) v JFS Governing Body. ${ }^{29}$ Citing many of the cases mentioned above, Lord Hope held that 'It has long been understood that it is not the business of the courts to intervene in matters of religion'. ${ }^{30}$ However, he went on to note the exception to this rule: 'It is just as well understood, however, that the divide is crossed when the parties to the dispute have deliberately left the sphere of matters spiritual over which the religious body has exclusive jurisdiction and engaged in matters that are regulated by the civil courts. ${ }^{31}$ This practice, which may be styled the Forbes $v$ Eden exception, ${ }^{32}$ means that courts will exceptionally intervene to enforce the laws of a religious group where there is a financial interest and in relation to the disposal and administration of property. In doing so, courts will adjudicate on and recognise religious law.

Courts recognise religious law in several other ways. ${ }^{33}$ For instance, religious law may enter the courtroom as part of the facts of the case ${ }^{34}$ and religious law may be introduced into the courtroom by expert witnesses. ${ }^{35}$ Pieces of State law may give effect to provisions of religious law or, more typically, religious practices. For instance, there are special rules on slaughter for Muslims and Jews ${ }^{36}$ and concerning the Sikh turban. ${ }^{37}$ Financial provisions

\footnotetext{
${ }^{27} R v$ Chief Rabbi, ex parte Wachmann [1992] 1 WLR 1036 at 1043.

${ }^{28}$ Sulaiman v Juffali [2002] 2 FCR 427 at para 47.

${ }^{29}$ [2009] UKSC 15.

${ }^{30}$ Para 157.

31 Para 158.

${ }^{32}$ After the leading case: Forbes $v$ Eden (1867) LR 1 Sc \& Div 568. See R Sandberg, Law and Religion (Cambridge University Press, 2011) chapter 4.

${ }^{33}$ See R Sandberg, 'Islam and English Law'(2010) 164 Law and Justice 27-44.

${ }^{34}$ Menski asserts that 'Some British judges, virtually every day, have to decide matters of Muslim law and are grateful for expert advice, while others resent expert involvement': W Menski, 'Law, Religion and Culture in Multicultural Britain' in R Mehdi et al (eds) Law and Religion in Multicultural Societies (DJØF Publishing, 2008) 45.

${ }^{35}$ For an example of this see Uddin v Choudhury \& Ors [2009] EWCA Civ 1205.

${ }^{36}$ Welfare of Animals (Slaughter or Killing) Regulations 1995 (SI 1995/731).

${ }^{37} \mathrm{Sikhs}$ are exempt from the requirement to wear a safety hat on a construction site and from the law relating to the wearing of protective headgear for motor cyclists: Employment Act 1989, s11; Road Traffic Act 1988, s 16; see S Poulter, Ethnicity, Law and Human Rights (Oxford University Press, 1998) ch. 8.
} 
allow Islamic banks, Shariah-compliant mortgages and Islamic Bonds. ${ }^{38}$ Perhaps the clearest example of State law recognising religious law is through the Divorce (Religious Marriages) Act 2002, discussed below.

Moreover, legislation has been enacted to recognise the jurisdiction of religious bodies to regulate aspects of their adherents' behaviour. The clearest example of this is through the Arbitration Act 1996, discussed below. In addition English law may be said to recognise religious laws through private international law. ${ }^{39}$ A typical example of this would be the recognition of marriages conducted overseas. The key test is whether the recognition complies with public policy. ${ }^{40}$ This was underlined by the Court of Appeal decision in $K C \&$ Anor v City of Westminster Social \& Community Services Dept,${ }^{41}$ concerning a purported marriage by telephone link between England and Bangladesh and a lack of mental capacity of one party. The Court of Appeal held that while this was a valid marriage under Islamic law and Bangladeshi law it was not valid under English law: the circumstances made the marriage sufficiently offensive to the conscience of the English court that it should refuse to recognise it.

\section{The Recognition of Religious Family Law in England and Wales}

This section focuses upon the recognition of religious family law by State law in England and Wales. This merits separate discussion given that our research focuses upon the marriage and divorce jurisdiction of the three institutions studied. ${ }^{42}$

\section{Marriage}

Religious jurisdiction over family matters has some limited recognition in the civil law of England and Wales. Indeed, at common law, the basic validity of a marriage was satisfied by

\footnotetext{
${ }^{38}$ R Hammond-Sharlot and P Booth, 'Islamic Law in the UK' (2008) Family Law 362. See also the provisions of the Finance Act 2007.

${ }^{39}$ The term 'international law' is often used to describe systems of law which govern the relationship between States, such as the legal instruments of the United Nations. However, technically this is known as 'public international Law'. And this is compared with 'private international law' which is the part of the national law of a country that establishes rules for dealing with cases involving the laws of other countries, foreign law. 'Private international law' is also known as conflict of laws.

${ }^{40}$ M Robe, 'Shari'a in a European Context' in R Grillo et al (ed) Legal Practice and Cultural Diversity (Ashgate, 2009) 93, 96-97.

${ }^{41}$ [2008] EWCA Civ 198 [2009] 2 WLR 185.

${ }^{42}$ For a more detailed discussion of English law on marriage and divorce see N Lowe and G Douglas, Bromley's Family Law (10 $0^{\text {th }}$ edn. Oxford University Press 2007) chapter 2 and 6 and G Douglas, An Introduction to Family Law $\left(2^{\text {nd }}\right.$ edn. Oxford University Press, 2004) chapter 2.
} 
simple conformity with canon law rules, ${ }^{43}$ and the common law itself ceded control over marriage status, entry and exit, to the ecclesiastical courts. Since 1753, English law has recognised the jurisdiction of certain other religious groups over control of entry into marriage. Thus, Jews and Quakers (though no other religious groups) were exempted from the requirements of Lord Hardwicke's Act of that year, the Clandestine Marriages Act, which, as its name suggests, sought to prevent the celebration of marriages in secret, through the imposition of rigidly prescribed preliminaries (particularly the calling of banns to ensure publicity of the impending union) and the performance of a Church of England ceremony open to the public. The penalty for failure to comply with these requirements was that the marriage would be regarded as lacking legal validity. In 1836, greater toleration of other religious persuasions led to the passage of new legislation which enabled Catholics and others to carry out marriages according to their own rites ${ }^{44}$ with the sanction and recognition of the state, provided that the fundamental civil rules of capacity to enter marriage were complied with (for example, that the marriage entered into would be monogamous and heterosexual) and that certain bureaucratic requirements were met (including the registration of the premises where the marriage would be performed, and the registration of the celebrant). Interestingly, relatively few Muslim, Sikh or Hindu places of religious worship have been so licensed, ${ }^{45}$ with these groups preferring to retain their own control over their religious rites but at the cost of the parties having to undergo a civil wedding ceremony as well if they wish to have civil legal recognition of their union. ${ }^{46}$

\section{Divorce}

In the early nineteenth century, there was no judicial system for divorce, so that the 1836 legislation did not need to contemplate the question whether recognised religious groups

\footnotetext{
${ }^{43}$ See R Probert, Marriage Law and Practice in the Long Eighteenth Century: A Reassessment (Cambridge Univesity Press, 2009) for a full discussion.

${ }^{44}$ Or for anyone to undergo a civil ceremony in a register office. The governing legislation is now the Marriage Act 1949.

${ }^{45}$ See ONS, Series FM2: No 35, Marriages 2007 (2010) Table 3.43. Of 40,405 buildings registered in England and Wales in 2007, 164 were Muslim, 161 Sikh and 281 'other': no figures are given specifically for Hindu temples.

46 There is a potential alternative way of achieving recognition, if the parties can bring themselves within the jurisprudence concerning 'presumption of marriage'. This arises where a couple cohabit and hold themselves out as married. In recent years, cases have arisen concerning the validity of marriages where couples have undergone religious marriage ceremonies which have not conformed to the requirements of the Marriage Act. In Chief Adjudication Officer v Bath [2000] 1 FLR 8, for example, the couple married in a Sikh temple which could not be proved to have been registered for the performance of weddings. The Court of Appeal upheld the validity of the marriage (for the purposes of establishing entitlement to a widow's pension) on the basis of the couple's cohabitation for nearly 40 years, and the lack of any evidence to show that the temple had not been registered.
} 
should have jurisdiction over the exit from marriages under their auspices as well as entry into them. Indeed, only Jews at that time would have had much familiarity with divorce as such a means of exit. In 1857, the jurisdiction of the ecclesiastical courts to regulate family matters was taken over by the state; in future, both the validity and the termination of marriages would be determined by the civil courts, and a Divorce Court was created for the first time. ${ }^{47}$ The reason for the state's monopoly over the exit from marriage is twofold. First, strictly speaking, the concession to religious groups to create legally binding marriages extends only to the rites by which the marriage is performed - the marriage itself is, as far as the civil law is concerned, a civil marriage, not a Jewish, Catholic or Muslim one, and is subject to all the civil rules concerning its validity. Secondly, the state asserts an interest in the consequences of the ending of a marriage for the parties themselves, their children and the wider society. It thus arrogates to itself the right to control the conditions under which a termination other than by death is to be achieved.

However, pressure from the Jewish community to provide some assistance with the problem of the agunah (chained wife) has led to some degree of linkage with religious law, through the enactment of the Divorce (Religious Marriages) Act 2002. Under Jewish law, a Beth Din (court) cannot (except in very rare circumstances) pronounce a divorce. Rather, the wife has to receive the bill of divorce - 'get' - from her husband. If he refuses to provide it, the marriage cannot be dissolved and the wife cannot marry again in accordance with Jewish rites, even if she obtains a civil divorce. ${ }^{48}$ In order to provide some leverage to a wife in this position, the $2002 \mathrm{Act}^{49}$ provides that a court may delay the making absolute of a civil divorce decree until the parties have certified that a religious divorce has been granted by the appropriate authorities. At present, only the Jewish religion is included within this provision, but it is open to other religions to seek to be 'prescribed' within the legislation.

The lack of mutual recognition by the civil and religious authorities of each others' pronouncements has created numerous legal problems, ranging from dealing with 'forced marriage ${ }^{50}$ (or marriage by proxy over the telephone) ${ }^{51}$ to the creation of 'limping divorces'

\footnotetext{
${ }^{47}$ Divorce and Matrimonial Causes Act 1857.

${ }^{48}$ This is the understanding within the Jewish Orthodox Community in the UK. Within Reform Judaism a get is not necessary as a civil divorce is regarded as sufficient to end the marriage. See The Beth Din: Jewish Courts in the UK, Centre for Social Cohesion (2009) 2.

${ }^{49}$ Now contained in s 10A of the Matrimonial Causes Act 1973.

${ }^{50}$ Now see the Forced Marriage (Civil Protection) Act 2007.
} 
whereby a union may be regarded as dissolved (or not) in religious law but not in civil law, and vice versa. These problems can be compounded where one religious ceremony takes place in another jurisdiction which may give it civil legal recognition so that the parties are married, not just in the eyes of their religion, but also under the law of one country, but not another. It is not surprising, therefore, that there have been increasing calls for greater recognition of religious laws as providing legal status to family members and equally a concern for caution in assessing the implications, both nationally and internationally, of such a move.

\section{The Recognition of Religious Courts in England and Wales}

English law tends to provide recognition of religious bodies and their laws rather than their courts. As a matter of public law in England and Wales, the variously styled courts and tribunals of all religious communities other than the Church of England are not subject to review by the courts of the State. ${ }^{52}$ In $R v$ Chief Rabbi, ex parte Wachmann ${ }^{53}$ the claimant sought judicial review of a decision by the Chief Rabbi, following a commission of enquiry, that Wachmann was no longer morally and religiously fit to hold rabbinical office, on grounds of procedural unfairness. Simon Brown J refused leave on the basis that there was no 'governmental interest in the decision-making power in question', and that the Chief Rabbi's 'functions are essentially to initiate spiritual and religious functions which the government could not and would not seek to discharge in his place were he to abdicate his regulatory responsibility'. This has been followed in relation to decisions made by an Imam, ${ }^{54}$ a Jewish Beth Din ${ }^{55}$ and the Provincial Court of the Church in Wales. ${ }^{56}$ This does not

\footnotetext{
${ }^{51}$ KC \& Anor v City of Westminster Social \& Community Services Dept. \& Anor [2008] EWCA Civ 198 [2009] 2 WLR 185.

52 The decisions of the courts of the Church of England are subject to judicial review (since it is established by law). Section 81 of the Ecclesiastical Jurisdiction Measure 1963 states that the High Court has power to enquire into contempt of the consistory court upon certification by the chancellor and recognises the supervisory jurisdiction of the High Court over the ecclesiastical court. It has been held that mandatory and prohibiting orders (as they are now styled) lie both to prevent and compel the exercise of jurisdiction by the ecclesiastical courts of the Church of England (See e.g. $R v$ North, ex parte Oakey [1927] 1 KB 491). Whilst it has been a long settled principle that a quashing order (formerly certiorari) does not lie to overturn the decision of an ecclesiastical court ( $R v$ Chancellor of St Edmundsbury and Ipswich Diocese, ex parte White [1948] 1 KB 195), this rule has been the subject of criticism $(R v$ Chancellor of Chichester Consistory Court, ex parte News Group Newspapers Ltd [1992] COD 48) and may be no longer sustainable, particularly in the light of general developments in judicial review (See $R v$ Exeter Consistory Court, ex parte Cornish (1998) 5 Ecc LJ 212). See M Hill, 'Judicial Review of Ecclesiastical Courts' in N Doe, M Hill and R Ombres (eds) English Canon Law (University of Wales Press, 1998) 104-114.

${ }^{53}$ [1992] 1 WLR 1036.

${ }^{54}$ R v Imam of Bury Park, ex parte Sulaiman Ali [1994] COD 142.

${ }^{55} R v$ London Beth Din ex parte Bloom [1998] COD 131.

${ }^{56} R v$ Provincial Court of the Church in Wales, ex parte Clifford Williams (1999) 5 Ecc LJ 129.
} 
mean, however, that there may not be a different outcome in a case where the necessary public element was present. Moreover, it does not mean that the decisions of these courts are not recognised by State courts. There are two different ways in which the decisions of religious courts are so recognised.

The first is through the doctrine of 'consensual compact' referred to above. This recognises that the rules and structures of voluntary associations are binding on assenting members. The doctrine is most fully elucidated in the Australian case of Scandrett $v$ Dowling, ${ }^{57}$ concerning the Church of England in Australia where it was held that 'the binding effect of the "voluntary consensual compact"...must have come from the shared faith of the members of the Church, or...their baptism in Christ', from 'a willingness to be bound to it because of shared faith...in foro conscientiae': 'its binding effect does not come from the availability of the secular sanctions of State courts of law'; 'the availability of these latter sanctions when spiritual matters become mixed with property matters is an incident of the consensual compact or contract'; so: 'where property is involved the consensual compact or contract is given the same effect, in relation to property matters, as if it were a common law contract, but does not in any way alter the primary basis of that compact or contract'. The doctrine of 'consensual compact' means that the rules and structures of voluntary associations are binding on assenting members and the courts of the State will exceptionally intervene to enforce the laws of a religious group where there is a financial interest and in relation to the disposal and administration of property. ${ }^{58}$

The second way in which the decisions of religious courts are recognised is through the Arbitration Act $1996 .^{59}$ This, the latest in a long line of similar statutes, provides that people are free to choose to have their disputes arbitrated outside the civil court system but recognised and enforced by the civil courts. ${ }^{60}$ The Act focuses not upon courts but upon people. Section 1 provides that 'parties should be free to agree how their disputes are resolved, subject only to such safeguards as are necessary in the public interest'. People can decide how disputes between them are to be resolved and once the parties decide to be bound

\footnotetext{
${ }^{57}$ [1992] 27 NSWLR 483.

${ }^{58}$ Forbes $v$ Eden (1867) LR 1 Sc \& Div 568.

${ }^{59}$ In Scotland, the law is updated and consolidated by the Arbitration (Scotland) Act 2010.

${ }^{60}$ See R Sandberg, 'Islam and English Law' (2010) 164 Law and Justice 27-44 ; and R Sandberg, Law and Religion (Cambridge University Press, 2011) chapter 9.
} 
by that decision then the secular courts will enforce that decision under the secular law of contract. There are two main limitations upon this, however.

\section{Limitations under the Arbitration Act 1996}

The first limitation is as stated in section 1: the secular courts will not enforce a decision where there is 'public policy which requires the court not to'. ${ }^{61}$ An agreement to arbitrate is just like any other contract: it is necessary to show a genuine agreement to arbitrate by both parties. ${ }^{62}$ Contracts obtained by duress or those formed with minors or the incapacitated will not be enforced. The agreement to arbitrate must be in writing. ${ }^{63}$

Section 33 of the Arbitration Act 1996 states the general duty of the arbitrator. It must:

(a) act fairly and impartially as between the parties, giving each party a reasonable opportunity of putting his case and dealing with that of his opponent, and (b) adopt procedures suitable to the circumstances of the particular case, avoiding unnecessary delay or expense, so as to provide a fair means for the resolution of the matters falling to be determined.

An arbitration award that does not comply with this can be set aside by the English court. ${ }^{64}$ This also applies where the agreement suffers from a 'serious irregularity' such as: exceeding its powers; failure to conduct the proceedings in accordance with the procedure agreed by the parties; failure to deal with all the issues that were put to it; and uncertainty or ambiguity as to the effect of the award. ${ }^{65}$

The importance of this public policy limitation is shown in the Court of Appeal decision in Soleimany $v$ Soleimany. ${ }^{66}$ In that case two Iranian Jewish merchants were exporting Persian carpets. This breached Iranian law. The two merchants fell out and took their dispute to the Beth Din. The Beth Din considered the illegality irrelevant under the applicable Jewish law and made an arbitration award. The Court of Appeal recognised this arbitration award made

\footnotetext{
${ }^{61}$ Kohn $v$ Wagschal and Ors [2007] EWCA Civ 1022 para 18.

${ }^{62}$ R Blacklett, 'The Status of Religious "Courts" in English Law' Disputes and International Arbitration Newsletter [2009] Disputes and International Arbitration Newsletter 11, 13.

${ }^{63}$ Arbitration Act 1996, s5.

${ }^{64} \mathrm{~S} 68(2)(\mathrm{a})$.

${ }^{65} \mathrm{~S} 68(2)$.

${ }^{66}$ [1999] QB 785.
} 
by the Beth Din as 'a valid agreement', ${ }^{67}$ but refused to enforce it on grounds that public policy would not allow an English court to enforce an illegal contract. ${ }^{68}$ This did not affect the court's conclusion that the Beth Din had jurisdiction. ${ }^{69}$

The second limitation is that the Act only applies to civil disputes; the criminal law is outside its operation. A victim and defendant could not agree that a breach of English criminal law be decided by arbitration. ${ }^{70}$ In English criminal law the 'dispute' is between the Crown and the defendant, not between the parties. English law provides no legal right for victims to have the defendant punished. ${ }^{71}$ Any imprisonment or physical punishment for a religious offence could not be recognised by the English court. Arbitration awards are enforced by the civil courts. ${ }^{72}$ With the exception of the offence of contempt of court, civil courts have no power to imprison anyone. A religious court enforcing punishment would find itself liable under English criminal law for assault or false imprisonment. ${ }^{73}$

Arbitration also has limited application under family law. Religious courts can grant religious divorces but not legal divorces. Individuals may seek mediation from a religious source but this is a non-binding method of dispute resolution. ${ }^{74}$

\section{The Effect of the Arbitration Act 1996}

The Arbitration Act 1996 is a facilitative piece of legislation, giving the parties the choice to agree to resolve their disputes outside the courtroom. If an agreement is made to arbitrate a dispute then any other legal proceedings may be stayed. ${ }^{75}$ The courts refuse to consider disputes which parties have decided to resolve by arbitration; rather than considering the

\footnotetext{
${ }^{67}$ At 798 .

${ }^{68}$ At 800 .

${ }^{69}$ At 799. See also London Export Corporation Limited v Jubilee Coffee Roasting Co Ltd [1958] 1 WLR 271, 277-278, per Diplock J: the question of whether 'as a matter of public policy, a particular award... ought not to be enforced and ought, therefore, to be set aside' is 'a second and quite separate question' because 'an arbitrator's award, unless set aside, entitles the beneficiary to call upon the executive power of the state to enforce it, and it is the function of the court to see that that executive power is not abused'

${ }^{70}$ R Blacklett, 'The Status of Religious "Courts" in English Law' [2009] Disputes and International Arbitration Newsletter 11, 13.

${ }^{71}$ Unless the crime is also a tort.

72 Under section 82 : 'legal proceedings' means civil proceedings

${ }^{73}$ R Blacklett, 'The Status of Religious "Courts” in English Law' [2009] Disputes and International Arbitration Newsletter 11, 14.

${ }^{74}$ The Beth Din: Jewish Courts in the UK, Centre for Social Cohesion (2009) 17.

${ }^{75}$ Arbitration Act 1996, s9(2).
} 
dispute themselves the courts enforce the decision the arbitrator has made. ${ }^{76}$ One of the few changes to the law of arbitration made by the $1996 \mathrm{Act}^{77}$ was the way in which it "very severely limited the right to apply to appeal from an arbitration award'. ${ }^{78}$

Under the Act, the parties are free to agree on the number of arbitrators to form the tribunal and whether there is to be a chairman or umpire. ${ }^{79}$ They are also free to decide upon the procedure for appointing the arbitrator or arbitrators. ${ }^{80}$ The parties are free to agree in what circumstances the authority of an arbitrator may be revoked. ${ }^{81}$ An arbitrator is not liable for anything done or omitted in the discharge or purported discharge of his functions as arbitrator unless the act or omission is shown to have been in bad faith. ${ }^{82}$

The Arbitration Act 1996 is largely used for commercial purposes and it has many advantages: it is private, cheaper and more flexible than full legal proceedings. ${ }^{83}$ It can be used to recognise the decisions of religious courts. ${ }^{84}$ Technically, it is not used by religious courts like the Beth Din themselves but is used by individual litigants who decide to take their dispute to a religious court. The key fact about arbitration is that it allows the parties to decide what law the arbitrators will use to decide their dispute. This extends to systems of religious law. Section 46 of the Arbitration Act 1996 enables parties to choose for disputes to be decided 'in accordance with other considerations' rather than 'in accordance with law'. ${ }^{85}$ For these purposes 'law' has generally been understood to mean the law of the

\footnotetext{
${ }^{76}$ R Blacklett, 'The Status of Religious "Courts" in English Law' [2009] Disputes and International Arbitration Newsletter 11, 11, 12

${ }^{77}$ The right to appeal had already been narrowed by the House of Lords in The Nema [1982] AC 724 and The Antoios [1985] AC 191. See the discussion in Cohen v Baram [1994] 2 Lloyd's Rep 138 at 142.

${ }^{78}$ The Act was 'intended to make successful applications for leave to appeal from an arbitration award very rare indeed': Saville LJ, 'The Arbitration Act 1996: What We Have Tried to Accomplish' [1997] Construction Law Review 410, 412. An appeal will only be granted if the court is satisfied that the decision was 'obviously wrong', or in relation to a question 'of general public importance', that the conclusion was at least 'open to serious doubt' and that 'despite the agreement of the parties to resolve the matter by arbitration, it is just and proper in the circumstances for the court to determine the question': Arbitration Act 1996, s69(3)(c)-(d).

${ }_{79}$ Arbitration Act 1996, s15.

${ }^{80} \mathrm{~S} 16$.

$81 \mathrm{~S} 23$.

${ }^{82} \mathrm{~S} 29$.

${ }^{83}$ R Blacklett, 'The Status of Religious "Courts" in English Law' [2009] Disputes and International Arbitration Newsletter 11, 12.

${ }^{84}$ A Tucker, 'The Archbishop's Unsatisfactory Legal Pluralism’ [2008] Public Law 463, 466.

${ }^{85}$ As Davidson noted, 'This is extraordinarily bold, as it apparently allows invocation of standards such as equity, by any criteria whatsoever, limited only by public policy': F P Davidson, 'The New Arbitration Act - A Model Law' [1997] Journal of Business Law 101, 121.
} 
State. $^{86}$ 'Other considerations', however, can extend to other systems of law that are not the law of the State such as religious law. ${ }^{87}$ Section 46 thus allows parties to choose for their dispute to be decided in accordance with systems of religious law, such as Jewish ${ }^{88}$ or Islamic ${ }^{89}$ law. Therefore parties may take a dispute to a religious court and enter into a contract to be bound by that court's decision.

However, the recent decision of the Court of Appeal in Jivraj v Hashwani ${ }^{90}$ has suggested that arbitration agreements which make distinctions on grounds of religion may fall foul of religious discrimination laws. The case concerned an arbitration agreement entered into in 1981 which required that all arbitrators were to come from the Ismaili community. When one of the parties sought to appoint an arbitrator from outside this community, he contended that he was permitted to do so because, whilst the requirement had been lawful when the agreement was made, it had been rendered unlawful by new laws prohibiting discrimination on grounds of religion or belief in relation to employment. ${ }^{91}$ The Court of Appeal agreed. ${ }^{92}$ Moore-Bick LJ held that the law prohibiting religious discrimination in relation to employment applied to arbitrators because employment was defined as meaning 'employment under a contract of service' and the nature of the arbitration was contractual. ${ }^{93}$ Moreover, the party seeking to enforce the requirement could not rely on the religious exception that permits a person with an 'ethos based on religion or belief' to insist that being of a particular religion or belief is an occupational requirement of a job. ${ }^{94}$ Since the arbitration agreement required the arbitrators to resolve the dispute in accordance with

\footnotetext{
${ }^{86}$ L Collins (ed) Dicey, Morris and Collins on the Conflict of Laws (14 ${ }^{\text {th }}$ edn, Sweet \& Maxwell, London 2006) para 16-050-16-055. See the discussion in Halpern v Halpern [2007] EWCA Civ 291 and Sayyed Mohammed Musawi v R.E. International (UK) Ltd [2007] EWHC 298.

${ }^{87}$ Section 46(2) states that: 'For this purpose the choice of laws of a country shall be understood to refer to the substantive laws of the country and not its conflict of laws rules'. Religious law could be therefore recognised as 'law' rather than 'another consideration' if that religious law is a substantive law in a country. See R Blacklett, 'The Status of Religious "Courts" in English Law' [2009] Disputes and International Arbitration Newsletter 11, 13.

${ }^{88}$ Halpern v Halpern [2007] EWCA Civ 291.

${ }^{89}$ Although Shariah law has also been regarded as having the status of foreign law: see A-Midani v Al-Mdiani [1999] CLC 904 at 912. 90 [2010] EWCA Civ 712.

${ }^{91}$ Employment Equality (Religion or Belief) Regulations 2003. The law is now to be found in the Equality Act 2010 .

${ }_{92}$ Compare the decision of the High Court which held that neither the Employment Equality (Religion or Belief) Regulations 2003 nor the Human Rights Act 1998 apply to the selection, engagement or appointment of arbitrators (unless a party to the particular arbitration agreement is a public authority): [2009] EWHC (Comm) 1364.

93 [2010] EWCA Civ 712 at para 14.

${ }^{94}$ Employment Equality (Religion or Belief) Regulations 2003. Reg 7(3). The exception is now to be found in Equality Act 2010, Schedule 19 Para 3.
} 
English law, it had not been shown that it was necessary for the arbitrators to be members of the Ismaili community. ${ }^{95}$ The long term implications of the Court of Appeal's judgment in Jivraj $v$ Hashwani upon the use of the Arbitration Act for religious purposes are unknown. At the very least the judgment suggests that parties who wish their disputes to be determined by representatives of a particular religious tradition must ensure that they have shown that this is a genuine occupational requirement. ${ }^{96}$

Moreover, the provisions of the Arbitration Act 1996 do not allow the State simply to wash its hands of these matters. Human rights instruments stress the importance of the right to a fair trial and States may be liable if basic standards are not met. At the level of the Untied Nations, Article 14 of the International Covenant on Civil and Political Rights protects the right to a fair trial. The Human Rights Committee have stressed that this right applies to arbitration by religious courts:

Article 14 is also relevant where a State, in its legal order, recognizes courts based on customary law, or religious courts, to carry out or entrusts them with judicial tasks. It must be ensured that such courts cannot hand down binding judgments recognized by the State, unless the following requirements are met: proceedings before such courts are limited to minor civil and criminal matters, meet the basic requirements of fair trial and other relevant guarantees of the Covenant, and their judgments are validated by State courts in light of the guarantees set out in the Covenant and can be challenged by the parties concerned in a procedure meeting the requirements of article 14 of the Covenant. These principles are notwithstanding the general obligation of the State to protect the rights under the Covenant of any persons affected by the operation of customary and religious courts. ${ }^{97}$

The right to fair trial is also safeguarded by Article 6 of the European Convention on Human Rights and this is part of English law by virtue of the Human Rights Act 1998. The European Court of Human Rights has insisted that States are under an obligation to ensure that standards concerning the right to a fair trial are met by religious courts. Pellegrini $v$ Italy ${ }^{98}$ concerned Catholic annulment proceedings in an ecclesiastical court where the applicant was not told the nature of proceedings in advance and was not allowed to read her husband's

\footnotetext{
95 [2010] EWCA Civ 712 at para 29.

${ }^{96}$ See R Sandberg, Law and Religion (Cambridge University Press, 2011) chapter 9.

${ }^{97}$ General Comment Number 32.

${ }^{98}$ Pellegrini v Italy (2002) 35 EHRR 2.
} 
witness statements. The Italian courts made operative the Vatican court's declaration of nullity. The European Court of Human Rights held that the proceedings in the ecclesiastical courts violated Article 6 ECHR in that the applicant's right to fair trial had been 'irremediably compromised'. Since the Vatican is not party to the Convention, the claim was made against the Italian State: the Court held that since the Italian courts made operative the Vatican court's declaration of nullity then the State was in breach of Article 6 since the courts 'should have refused to confirm the outcome of such unfair proceedings' and that they had 'failed in their duty to check ... that the applicant had enjoyed a fair trial in the ecclesiastical proceedings'. It follows from Pellegrini v Italy that the United Kingdom would be in breach of Article 6 if a religious court failed to meet Article 6 standards as to the right to a fair trial and then that decision was enforced under the Arbitration Act 1996.

There are numerous examples of the decisions of religious courts being enforced under the Arbitration Act - particularly the Jewish Beth Din. ${ }^{99}$ There are fewer examples in respect of Islamic courts and there is evidence of at least one case where the decision of the Islamic Sharia Council of London (ISC) was not so enforced, ${ }^{100}$ the decision in A-Midani v AlMidani. ${ }^{101}$ However, on the facts of that case it was clear that the parties had not agreed to arbitration by the ISC. ${ }^{102}$ Whilst it is true that other Islamic courts and tribunals have generally not operated under the Arbitration Act, A-Midani v Al-Midani does not mean an Islamic court or tribunal can never operate under the Arbitration Act. As the High Court made clear, that the ISC was not 'in this instance at any rate, an arbitration tribunal'. ${ }^{103}$ There is now at least one clear example of an Islamic court operating under the Arbitration Act 1996: the Muslim Arbitration Tribunal (MAT). ${ }^{104}$ The MAT website makes it clear that they operate under the Arbitration Act 1996. ${ }^{105}$ They deal with all areas of civil and personal religious law but not divorce proceedings (other than a religious divorce), the care of children and criminal matters. ${ }^{106}$

\footnotetext{
99 The Beth Din sits as a 'court of arbitration': Cohen v Baram [1994] 2 Lloyd's Rep 138. For a recent example see Kohn v Wagschal and Ors [2007] EWCA Civ 1022.

${ }^{100}$ S Knights, Freedom of Religion, Minorities and the Law (Oxford University Press, 2007) 76.

101 [1999] CLC 904.

102 The High Court examined the ISC's brochure and commented that the ISC 'acknowledges that it "is not yet legally recognised by the authorities in the UK", but represents itself as gaining recognition and confidence among the Islamic community and at large. It would seem that Islamic divorce and matrimonial questions in general are the focus of its advisory and judicial work': at.911.

${ }^{103}$ At 913.

${ }^{104}$ See, further R Sandberg, 'Islam and English Law' (2010) 164 Law \& Justice 27-44.

$105 \mathrm{http}: / /$ www.matribunal.com/

${ }^{106}$ See further Part two of this Commentary.
} 
Even religious courts which use the Arbitration Act 1996, such as the Beth Din and the MAT, also operate outside the Arbitration Act. A distinction is sometimes drawn between their 'legal' functions under the Arbitration Act and 'religious' functions. For instance, a study of the Beth Din by the Centre for Social Cohesion states that: 'The Beth Din serves two distinct functions for members of the Jewish communities in the UK'. First, 'Jewish courts function as legally binding arbitration tribunals for civil cases'. Second, 'The Beth Din also functions as a religious - and not legal - authority [ruling] in a variety of religious matters' such as designating religious holidays or granting religious divorces'. ${ }^{107}$ It is often suggested that where religious courts do not use the Arbitration Act then they are operating extra-legally and their decisions are not legally binding at all. However, this is not the case. As we have seen, the doctrine of 'consensual compact' means that the rules and structures of voluntary associations are binding on assenting members and the courts of the State will exceptionally intervene to enforce the laws of a religious group where there is a financial interest and in relation to the disposal and administration of property. ${ }^{108}$

${ }^{107}$ The Beth Din: Jewish Courts in the UK, Centre for Social Cohesion (2009) 4.

${ }^{108}$ Forbes $v$ Eden (1867) LR 1 Sc \& Div 568. 


\section{Part Two: Religious Courts in England and Wales}

\section{Introduction}

Whilst the first part of this commentary has sought to elucidate the legal status of religious laws and courts, this second part examines the extent to which religious courts operate in the UK today, with particular reference to the three institutions that we have studyied in greater depth. It falls into three sections. The first section examines the existence of religious courts in the UK, with special reference to Judaism, Islam and Christianity. The second section examines the organisational structure of the three selected institutions where we have undertaken our empirical investigation: the Jewish London Beth Din, Family Division; the Shariah Council of the Birmingham Central Mosque and the Catholic National Tribunal for Wales in Cardiff. The third section explores the jurisdiction each of these institutions has in relation to marriage, divorce and remarriage and how this is administered and reinforced.

\section{Religious Courts in the UK}

It is difficult to quantify the number of religious courts that exists within the United Kingdom. This is partly due to the fact that there is no general consensus as to what is meant by the terms 'religious' or 'court'. With the exception of the courts of the Church of England, ${ }^{109}$ the courts that belong to other faith communities are not part of the State court system. $^{110}$ They are instead formed by individual religious organisations and are variously styled according to the needs of the faith community in question. Some of these courts bear few similarities to the courts found in civil law. In some religious traditions, there is no distinction between executive, judicial and legislative functions. Moreover, whilst some courts are very formal with proceedings taking place in designated rooms, in other religious groups the situation is much more informal. ${ }^{111}$ There are also marked differences within religious traditions and there is significant regional variation, depending upon resources,

\footnotetext{
${ }^{109}$ On which see N Doe, The Legal Framework of the Church of England: A Critical Study in a Comparative Context (Clarendon Press, Oxford 1996) chapter 5 and M Hill, Ecclesiastical Law ( $3^{\text {rd }}$ edn, Oxford University Press, 2007) chapters 6 and 7.

${ }^{110}$ Although occasionally these courts are recognised by the State. The Welsh Church Act 1914, for instance, permitted the Church in Wales to create its own provided that they did not exercise coercive jurisdiction and their decisions cannot be appealed against (s3(3)). These courts were very similar to those which exist in the Church of England but are not part of the State court system. See N Doe, The Law of the Church in Wales (University of Wales Press, Cardiff 2002) chapter 5.

${ }^{111}$ Beckford and Richardson contrast the highly formal religious laws of the Roman Catholic Church with Islam, Hinduism and Buddhism which 'lack single authoritative organisations for regulating their national and transnational activities': J A Beckford and J T Richardson 'Religion and Regulation' in J A Beckford and N J Demerath (eds) The Sage Handbook of the Sociology of Religion (Sage, London 2007) 396, 399.
} 
perceived needs and the mindsets of those responsible. Furthermore, the nature and role of religious courts evolve over time in response to changes in theological interpretation, social need and changes in civil law. ${ }^{112}$

Our empirical study explores three selected 'religious courts' in England and Wales: the Jewish London Beth Din, Family Division; the Shariah Council of the Birmingham Central Mosque and the Catholic National Tribunal for Wales in Cardiff. This section seeks to provide a contextual setting for these courts, exploring the existence of Jewish, Islamic and Catholic courts in the UK.

\section{Judaism}

Like Islam, Judaism is often seen as being a religion of law. ${ }^{113}$ According to Neusner and Sonn, the law of Judaism is to be found in 'the record of the tradition, written and oral, of God's revelation to Moses at Sinai'. ${ }^{114}$ The written tradition is found in the Hebrew Scriptures whilst the oral ${ }^{115}$ tradition is found in a variety of documents, commentaries, codes and responsa (the replies written by sages in response to questions posed by the faithful). ${ }^{116}$ There is a long history of courts existing within Judaism. As Neusner and Sonn note, 'the law of Judaism provides for three correlated but autonomous institutions to exercise the power to inflict sanctions in the enforcement of the law: God, the court, and the temple'. ${ }^{117}$

\footnotetext{
${ }^{112}$ For example, see the increase in tribunals in the Church of England and current reform of the ecclesiastical courts of the Church in Wales.

${ }^{113}$ See J Neusner and T Sonn, Comparing Religions Through Law (Routledge, London 1999) chapter 1.

${ }^{114}$ Ibid 18. The Pentateuch contain 613 commandments revealed by God to Moses which includes statutes concerned with ritual performances, obligations between humans and God as well as judgements of rituals laws for society, regarding for example murder and theft. The commandments include 365 prohibitions and 248 prescriptions. See D Cohn-Sherbok, Judaism: History, Belief and Practice (Routledge, Oxford 2003).

${ }^{115}$ The word 'oral' here (and elsewhere in this commentary) does not mean that these teachings are not now written down. It refers instead to the fact that the teachings did not originate in a 'received' holy text. Neusner and Sonn disitisnguih between the 'written tradition' in Judaism which they refer to as 'the Torah in writing' and the 'oral tradition' which they refer to as 'the Torah in memory'. They note that this 'oral' traidtion was 'ultimatley preserverd in a variety of documents which reached closure in the first sixcty centuries': J Neusner and T Sonn, Comparing Religions Through Law (Routledge, London 1999) 18-19.

${ }^{116}$ The Mishna, a text composed by Juda Ha-Nasr in the second century of Judaism, is the most important book of law after the Torah and has supplied teachers and judges with an authoritative guide to Jewish legal tradition. Subsequent discussions of the content of Jewish law are contained within the Talmud which incorporates the Mishna. Later discussions are known as Gamara. See D Cohn-Shebok, Judaism: History, Belief and Practice (Routledge, Oxford 2003).

${ }^{117}$ J Neusner and T Sonn, Comparing Religions Through Law (Routledge, London 1999) 104. Several verses in the Torah make reference to the setting up of a court system which led to the forming of Sanhedrin: scoping interview.
} 
No figures exist concerning the number of Jewish courts in the United Kingdom today. The interpretation and observance of Jewish law varies amongst the different branches of Judaism in Britain (Orthodox, Masorti, Reform and Liberal). ${ }^{118}$ The different branches within Judaism have their own rabbinic authorities and interpret Jewish law for their associated synagogues. ${ }^{119}$ The study of the Beth Din by the Centre for Social Cohesion states that the Liberal, Masorti and Reform movements, which collectively represent just over a third of Britain's Jews, ${ }^{120}$ run separate Batei Din which 'span from the traditional to the progressive both in their practices and attitude to Jewish law'. ${ }^{121}$ Several different courts exist within the Orthodox tradition. ${ }^{122}$ In addition to the London Beth Din which is the subject of our investigation, other orthodox courts include: ${ }^{123}$ the Beth Din of the Federation of Synagogues in London, ${ }^{124}$ the Sephardic Beth Din of the Spanish \& Portugal Jews' Congregation in London $^{125}$ and the Beth Din of the Union of Orthodox Hebrew Congregations.

The London Beth Din is part of the United Synagogue, an umbrella organisation representing the majority of Britain's Orthodox Jewish community. ${ }^{126}$ The synagogues aligned to the United Synagogue recognise the authority of the Chief Rabbi, an office which has existed since before the eighteenth century. The London Beth Din has its origins in the meetings of the Chef Rabbi and other Rabbis to carry out conversions, divorces and arbitrations, probably on an ad hoc manner. Like the office of the Chief Rabbi, the Beth Din pre-dates the United Synagogue which was established for religious purposes under the Jewish United Synagogues Act 1870. Over time, the Beth Din was brought under the remit of the United Synagogue. ${ }^{127}$ Today, one of the functions of the United Synagogue is:

\footnotetext{
${ }^{118}$ See Board of Deputies, 'Jewish Family Life and Customs' <www.boardofdeputies.org.uk/file/FamilyLifeCustoms.pdf> 
To provide an ecclesiastical court of Jewish law (the Court of the Chief Rabbi) as well as the preparation, production and supervision of food and drink for Jewish people to enable such persons to better conform to their religious beliefs. ${ }^{128}$

The Beth Din is funded by the United Synagogue and its Dayanim are employees of the United Synagogue. Jewish courts perform a wide range of different functions, including the regulation of slaughter and kosher food, conversions, ${ }^{129}$ arbitrating agreements, burial practices, determining personal status and a host of issues concerning marriage and divorce.

\section{Islam}

As with Judaism, Islamic law is considered to regulate all aspects of a believer's life. ${ }^{130}$ Its ultimate revealed sources are in two forms: written and oral. ${ }^{131}$ The written text, the Qur'an, believed to be delivered though the prophet Muhammad ${ }^{132}$ is complemented by an oral tradition, the Sunnah. ${ }^{133}$ An important distinction exists between the shariah, 'the source from which the law is derived', and Fiqh, 'the method by which law is derived and applied': while Shariah 'is divine in nature and thus immutable', Fiqh 'is a human product that may change according to time and circumstances'. ${ }^{134}$ There is a long tradition within Islam of

\footnotetext{
${ }^{128}$ Statutes of the United Synagogue 1999, 5.7.

129 'While Judaism is not a proselytising religion, conversions are carried out by courts of Jewish religious law (Beth Din, plural Batei Din). Each Beth Din has different arrangements and not all foreign or even Israeli conversions are necessarily accepted by the United Kingdom Batei Din.': Board of Deputies, 'Jewish Life and Customs' 7.

${ }^{130}$ For example, Islamic law 'is much more than law in the modern sense'; 'It also functions as a vocabulary of morality and justice'; It is a 'total discourse', whereby all kinds of institutions find simultaneous expression: religious, legal, moral and economic': S Zubaida, Law and Power in the Islamic World (I B Tauris, London 2003) 1; Islamic law is 'a moral code, a field of abstract theological investigation, and a process of addressing the relationships and conflicts that may arise among the faithful' and 'is intimately entwined with other portions of Islamic culture and society' (L Rosen, The Justice of Islam (Oxford University Press, Oxford 2000) ix)).

${ }^{131}$ J Neusner and T Sonn, Comparing Religions Through Law (Routledge, London 1999) 19. As discussed above, the 'oral' label does not mean that these teachings were not written down. The label is used to distinguish between the 'received' written text of the Q'uran which was delivered through the Prophet Muhammed and the oral tradition whuich was carried in reports which rrelated to the words and deeds of the prophets.

${ }^{132}$ Of the approximately 6000 verses included in the Qur'an strict legal content is only attached to about 80 verses. These tend to focus upon issues of Islamic Family Law particularly with regard to divorce (talaq): J Rehman, 'The Sharia, Islamic Family Laws and International Human Rights Law: Examining the theory and practice of polygamy and talaq' (2007) 21 International Journal of Law, Policy and the Family 108.

${ }^{133}$ These are comprised of the traditions and practices of the Prophet Muhammad. These were carried in reports (known as hadith) which were later collected and codified. The Sunni collections refer to Traditions (Hadith) that have been collected into six canonical compilations and the two most authentic are al-Bukhari (d. 870) and Muslim ibn al Hajjaj (d. 874). The Shia have their own collections and also rely on the sayings and doings of their holy Imams: J Rehman, 'The Sharia, Islamic Family Laws and International Human Rights Law: Examining the theory and practice of polygamy and talaq' (2007) 21 International Journal of Law, Policy and the Family 108.

${ }^{134}$ M A Baderin, International Human Rights and Islamic Law (Oxford University Press, Oxford 2003) 33-34. However, such a clear-cut distinction is controversial: for Zubaida, the revealed Sharia 'is largely man-made, based on exegesis, interpretations, analogies, and extensive borrowing from customary practices ... and existing local middle Eastern legal traditions' as well as 'possible adaptations of Roman law'. Indeed: 'This hybrid
} 
religious leaders and scholars interpreting and deciding upon questions of Islamic law. ${ }^{135}$ Those who possess all the necessary textual and rational skills to do so acquire the status of Mufti - someone who issues fatwas. A fatwa is simply a ruling on a matter of shariah law, usually issued in response to a questions raised by a member of the public. The fashioning of such rulings forms the basis of some of the work of Shariah Councils. ${ }^{136}$

Existing research cannot confirm the precise number or nature of all the systems of applying Muslim legal norms in the UK today. It is clear that there is significant use of informal forms of dispute resolution within Muslim communities, particularly in the context of Muslim family law. ${ }^{137}$ Moreover, a report for Civitas has asserted that there are at least 85 Shariah Councils operating mainly out of mosques around the country with 13 tribunals operating within the network administered by the Islamic Sharia Council based in Leyton, ${ }^{138}$ and there are three run by the Association of Muslim Lawyers. ${ }^{139}$ In addition to these exists the Muslim Arbitration Tribunal (MAT). ${ }^{140}$ The MAT, the Islamic Sharia Council and the

formation poses interesting questions for modern contexts of reform and "fundamentalism": both try to rescue the divine message from the man-made historical accretions, but come to quite different conclusions regarding the essence of the divine message': S Zubaida, Law and Power in the Islamic World (I B Tauris, London 2003) 10 .

${ }^{135}$ These leaders and scholars refer to themselves under various names or titles (e.g., Registrar, Imam, Sheikh, Maulana or Qadi). Each term can be translated as religious scholar and the variation in usage was due to personal preference. Bano notes that the term 'judge' does not tend to be used and that such personnel were keen to underline the fact that their verdicts were not legally binding under English law but served to uphold the moral authority of the Muslim community: S Bano, 'Islamic Family Arbitration, Justice and Human Rights in Britain' (2007) (1) Social Justice and Global Development Law

<http://www.go.warwick.ac.uk/elj/lgd/2007_1/bano>

${ }^{136}$ According to a report for Civitas, some of these rulings appear on websites such as Ask Imam or Islam Online, and are available to Sharia courts where they are chosen on the strength of the mufti who issued them or the validity of his religious affiliation (see D MacEoin, 'Sharia Law or 'One Law for All?' (Civitas, The Cromwell Press Group 2009) <http://www.civitas.org.uk/pdf/ShariaLawOrOneLawForAll.pdf>). However, these websites (such as the one on the Birmingham Central Mosque website) appear to be more a source of religious advice and guidance (rather than a legal ruling or fatwa) and are based on the responses of individual Imams to specific questions from the Muslim community. However on the Q\&A section on the Islamic Sharia Council website responses to questions are posted as 'fatwa's'.

${ }^{137}$ M Malik, 'Muslim Legal Norms and the Integration of European Muslims (EUI Working Paper RSCAS 2009/29, July 2009, Italy: European University Institute) .

${ }^{138}$ The Islamic Sharia Council is a registered charity and its constitution empowers it to preside over cases where either party has been living permanently in this country and at least one of the parties has made an application, requesting the Council's judgment. Islamic Sharia Council <http://www.islamic-sharia.org> ${ }^{139}$ D MacEoin, 'Sharia Law or 'One Law for All?' (Civitas, The Cromwell Press Group 2009).

${ }^{140}$ The MAT makes it clear that they operate under the Arbitration Act 1996. It claims to deal with all areas of civil and personal religious law but not 'divorce proceedings (other than a religious divorce), child custody and criminal matters'. It also has a reconciliation role. Their Rules of Procedure state that it acknowledges that it must operate within the framework of the secular law. In fact, they state that they had 'modelled [the Rules on Procedure] on existing tribunal procedural rules'. They do not state which tribunal rules. The Rules of Procedure allow for any applicant to be legally represented if they so wish. The adjudication panel consists of two members, a legally qualified member and a recognised Islamic Scholar. See the MAT website (http://www.matribunal.com/) and also a written submission on the Interfaith Legal Advisers Network (ILAN) website (<http://www.law.cf.ac.uk/clr/networks/ilan4.html>). 
Birmingham Shariah Council (which is the subject of our study) ${ }^{141}$ all claim that they do not represent any single school of thought and will base their 'verdicts' upon rulings derived from the four main schools of Sunni ${ }^{142}$ brought together with other sources from the Sunni tradition, as well as minority interpretations. ${ }^{143}$

Shariah Councils serve as alternative forums for dispute resolution which apply Muslim legal and ethical principles as well as the cultural norms of local communities. ${ }^{144}$ Shariah Councils have three main functions; reconciliation and mediation: issuing Muslim divorce certificates; and producing expert opinion reports on Muslim family law and practice. ${ }^{145}$ However the main role of Shariah Councils is that of administering Islamic family law and particularly Islamic divorce. For instance, $95 \%$ of correspondence received by the Islamic Sharia Council to date has related to matrimonial problems faced by Muslims in the UK. ${ }^{146}$

\section{Christianity}

Unlike the categories, Jewish law and Islamic law, the term 'Christian law' is not in regular use. ${ }^{147}$ Although the term 'canon law' is sometimes employed to provide the Christian equivalent of systems of religious law, ${ }^{148}$ the term is often reserved for the Catholic, Anglican and Orthodox churches. Even in that context, the term is problematic, ${ }^{149}$ being employed in various ways, some very narrow; ${ }^{150}$ some very wide. ${ }^{151}$ It is often asserted that other

\footnotetext{
${ }^{141}$ Birmingham Central Mosque <http://centralmosque.org.uk>

${ }^{142}$ Hanafi, Maliki, Shafi'I and Hanbali

${ }^{143}$ For Yilmaz this modern phenomenon (Takayyar) which denotes selection of the most appealing and appropriate doctrine from amongst the existing Islamic schools provides a more equitable solution in circumstances where insistence on the application of the principles derived from any one school would lead to injustice: I Yilmaz, Law as Chameleon: The Question of Incorporation of Muslim Personal Law into English Law’ (2001) 21 Journal of Muslim Minority Affairs 297.

${ }^{144}$ M Malik, 'Muslim Legal Norms and the Integration of European Muslims' (EUI Working Paper RSCAS 2009/29, July 2009, Italy: European University Institute) < http://cadmus.eui.eu/handle/1814/11653>

${ }^{145}$ S Bano, 'Islamic Family Arbitration, Justice and Human Rights in Britain' (2007) (1) Social Justice and Global Development Law <http://www.go.warwick.ac.uk/elj/lgd/2007_1/bano>

${ }^{146}$ Islamic Sharia Council <http://www.islamic-sharia.org>

${ }^{147}$ For arguments that it can, and should be, see N Doe, 'Modern Church Law' in J Witte Jr and F S Alexander (eds) Christianity and Law (Cambridge University Press, Cambridge 2008) 274 and N Doe, 'The Concept of Christian Law - A Case Study: Concepts of "a Church" in a Comparative and Ecumenical Context' in N Doe and R Sandberg (eds), Law and Religion: New Horizons (Peeters, 2010) 243.

${ }^{148}$ See, for instance, S Ferrari, 'Canon Law as a Religious Legal System' in A Huxley (ed), Religion, Law and Tradition: Comparative Studies in Religious Law (Routledge, London 2002) 49, which focuses purely on the law of the Roman Catholic Church.

${ }^{149}$ See N Doe, The Legal Framework of the Church of England (Clarendon Press, Oxford 1996) 12-13.

${ }^{150}$ For example, "the expression "canon law" is used restrictively to mean the Canons of the Church of England': M Hill, Ecclesiastical Law $3^{\text {rd }}$ edn (Oxford University Press, Oxford 2007) 2.

${ }^{151}$ See for instance, the assertion that canon law is 'so much of the law of England as is concerned with the regulation of the affairs of the Church of England'; its sources include: theology (embracing divine law); the
} 
Christian denominations do not have canon law. However, as Arthur concluded, 'the Methodist ${ }^{152}$ and United Reformed Churches have set up structures of varying flexibility that act like Canon Law, ${ }^{153}$ as have the Baptists. ${ }^{154}$ Indeed, most Christian groups have rules which are binding, usually on both an international and local level. ${ }^{155}$ These laws can be compared with those found within other world religions, especially if it is remembered that the terms 'Jewish law', 'Islamic law' or 'Hindu law' refer to 'pluralist' legal systems rather than to 'a solidly uniform legal system'. ${ }^{156}$

The focus in this study is on the (Roman) Catholic Church. The laws of different Christian churches are comprised of both the rules found in sacred texts and also the more practical rules developed by religious groups themselves ${ }^{157}$ and this is true of the law of the Catholic Church, which 'springs from the will of Christ, but its minute and detailed rules come from human agents...that is, the pope and the bishops'. ${ }^{158}$ The Code of Canon Law ${ }^{159}$ is the central and coordinating compilation of the Western (or Latin) church and is the primary source of reference for Catholic canon law. ${ }^{160}$ The Code outlines specific processes for the resolution of disputes or offences within the community. ${ }^{161}$ Regulations for marrying, the conduct of marriage and the prohibition of divorce are outlined with particular specificity. ${ }^{162}$

common law of England; and Acts of Parliament: T Briden and B Hanson, Moore's Introduction to English Canon Law $3^{\text {rd }}$ edn (Mowbrays, London 1992) 4.

${ }^{152}$ See also in relation to the Methodist Church, G Powell, Towards a Definition of Global Methodism: A Comparative Study of the Canon Laws of Methodist Churches (Doctoral Thesis, Cardiff University forthcoming).

${ }^{153} \mathrm{G}$ Arthur, Law, Liberty and Church: Authority and Justice in the Major Churches in England (Ashgate, Aldershot 2006) 172. See also F Cranmer 'Regulation in the Religious Society of Friends' (2003) 7 Ecclesiastical Law Journal 176.

${ }^{154}$ Even though Arthur concludes that there is no equivalent to canon law in the Baptist Church, where issues of church discipline are the responsibility of the local church, Doe has included Baptists in his study of 'Modern Church Law' pointing out that the Baptist Union of Great Britain and Ireland and the Baptist World Alliance both have constitutions. N Doe, 'Modern Church Law' in J Witte Jr and F S Alexander (eds) Christianity and Law (Cambridge University Press, Cambridge 2008) 271 at 274, 275, 277.

${ }^{155}$ Ibid 271.

${ }^{156}$ W Menski, Hindu Law: Beyond Tradition and Modernity (Oxford University Press, Oxford 2003) 47, fn 33.

${ }^{157}$ In the Anglican context, this difference is elucidated in the Principles of Canon Law which distinguishes between 'fundamental authoritative sources of law' namely 'Scripture, tradition and reason' and 'formal sources' such as 'constitutions, canons, rules, regulations and other instruments': Principles 4(1) and 4(2).

${ }^{158}$ L Örsy, 'Towards a Theological Conception of Canon Law' in J Hite and DJ Ward (eds) Readings, Cases, Materials in Canon Law (Collegeville 1990) 10, 11.

${ }^{159}$ First codified in 1917, the current Code originates from 1983.

${ }^{160}$ For a full discussion of the sources of Catholic Canon law see J A Coriden, Introduction to Canon Law (Cassell Publishers, London 1991) 31.

${ }^{161}$ As Coriden notes, "“Canon law" is the name for the church's own system of regulations, its rules of discipline': J A Coriden, The Rights of Catholics in the Church (Paulist Press, New York 2007) xii-xiii. ${ }^{162}$ Interestingly, the Code 'does not, for the most part, regulate liturgical matters': J A Coriden, Introduction to Canon Law (Cassell Publishers, London 1991) 40. See Canon 2. 
The Church has its own court system. ${ }^{163}$ However, the judicial process is treated as a last resort. ${ }^{164}$ This is true even once the process has begun: the parties are under a canonical duty to settle amicably, promptly and equitably out of court. ${ }^{165}$ The object of a trial is to prosecute or to vindicate the rights of physical or juridical persons, to declare juridical facts or to declare the penalty for offences. ${ }^{166}$ Judicial power is exercised by judges or judicial colleges. ${ }^{167}$ The courts are ordered hierarchically. ${ }^{168}$ The tribunal of first instance is the diocesan court. ${ }^{169}$ This is presided over by the Bishop who may exercise judicial power personally ${ }^{170}$ or through others. ${ }^{171}$ The Bishop's judge is the judicial vicar who may be assisted by adjutant judicial vicars who must be priests. ${ }^{172}$ Lay judges may be appointed. ${ }^{173}$ Other court personnel include: ${ }^{174}$

- Auditors (who gather evidence) ${ }^{175}$

- The Promoter of Justice (who provides for the public good, which is at stake whenever the Bishop says it is or when stated by the law that it is, such as in nullity of marriage cases) ${ }^{176}$

- The Defender of the Bond (who must be summoned in all cases involving nullity of marriage. Their role is to propose and clarify all that can be reasonably argued against nullity or dissolution), ${ }^{177}$

\footnotetext{
${ }^{163}$ We are indebted to Eithne D'Auria for her help in preparing this part of the commentary.

${ }^{164} \mathrm{~N}$ Doe, The Legal Framework of the Church of England: A Critical Study in a Comparative Context (Clarendon Press, Oxford 1996) 142.

${ }^{165}$ Canon 1446. See also Canons 1713-16 concerning arbitration.

${ }^{166}$ Canon 1400.

${ }^{167}$ Canon 135.

${ }^{168}$ N Doe, The Legal Framework of the Church of England: A Critical Study in a Comparative Context (Clarendon Press, Oxford 1996) 151.

${ }^{169}$ The term 'diocese' refers to the territories that are subject to the jurisdiction of Bishops. At the smallest level, dioceses are divided into parishes.

${ }^{170}$ Unless he has a direct interest.

${ }^{171}$ Canon 1419.

${ }^{172}$ Canon 1420. The Judicial Vicar is appointed by the Bishop. He has vicarious power - exercised in the Bishops name, not their own. The Judicial Vicar must be confirmed on the arrival of a new Bishop and the office is held for a defined period of time. The judicial vicar and his assistants must be of unimpaired reputation and must hold a doctorate or minimum of licentiates in Canon Law.

${ }^{173}$ Canons 129 and 1421. Since 1971 lay persons may be appointed as Judges in matrimonial cases. Power is in the College of the Church by Divine Institution, not in the persons. Sole judges must be clerics so a layperson will only form part of the college.

${ }^{174}$ A judge, Promoter, Defender or Auditor cannot act as a judge in another instance of the same case, cannot act in cases where they might have an interest, affinity or friendship. The Bishop deals with objections against the judge and all other officials

${ }^{175}$ Canon 1428.

${ }^{176}$ Canons 1430-1436

${ }^{177}$ Ibid. Defender or Promoter roles can be held at the same time by the same person but not in the same case. Both roles require the minimum if a licentiate if not a doctorate.
} 
- The Notary (who must be present during each procedure. The procedure is null and void if not signed by the notary) ${ }^{178}$

- Advocates (whose duty is the discovery, ascertainment and legal assertion of truth and objective fact), ${ }^{179}$ and

- Pro-Curators (who may be involved in cases but not as members of the tribunal: they represent parties). ${ }^{180}$

Diocesan courts are almost exclusively occupied with matrimonial cases - the adjudication of the validity of marriages. ${ }^{181}$ With papal approval dioceses can group together and operate a single court for that diocesan group. ${ }^{182}$ In the case of inter-diocesan tribunals, the group of bishops or a bishop designated by them has all the powers of the diocesan bishop. The National Tribunal for Wales (our case study) provides an example of an inter-diocesan tribunal. There is also only one tribunal in Scotland. In contrast, in England, every diocese has its own diocesan court. There is an elaborate system of rights of appeal. ${ }^{183}$ There are four levels of Church tribunals: Diocesan; Metropolitan (at the level of the Archdiocese); Regional and the Holy See. ${ }^{184}$

\section{The Three Institutions}

Having examined the existence of Jewish, Islamic and Catholic courts in the United Kingdom, this section seeks to explore the three selected case studies in further depth, focusing upon their organisational structure.

\section{The Beth Din in London}

The formal title of the London Beth Din is the 'Beth Din of London and the Country'. This denotes the institution's national role, which has become increasingly important in recent

\footnotetext{
${ }^{178}$ Canon 1437.

${ }^{179}$ Canon 1481-1490.

${ }^{180}$ Ibid. See especially Canon 1490: 'As far as possible, permanent advocates and procurators are to be appointed in each tribunal and to receive a salary from the tribunal. They are to exercise their office, particularly in matrimonial cases, for parties who may wish to choose them'.

${ }^{181}$ Compare the Church of England where the busiest courts are those exercising faculty jurisdiction concerning church property: N Doe, The Legal Framework of the Church of England: A Critical Study in a Comparative Context (Clarendon Press, Oxford 1996) 143. This may be because of the close nexus between the marriage law of the Church of England and the law of the State. This is one of the reasons why we have chosen a Catholic court as the Christian case study.

182 Canon 1423.

${ }^{183}$ See, e.g., N Doe, The Legal Framework of the Church of England: A Critical Study in a Comparative Context (Clarendon Press, Oxford 1996) 151.

${ }^{184}$ The Roman Rota serves as an appeal court and the Apostolic Signatura serves as a supervisory court. See Canons 1442-1145.
} 
times because of the decline in the size of Jewish communities and local Batei Din in Britain. ${ }^{185}$ The London Beth Din is situated in a building owned by the United Synagogue in North London. The building includes a 'court room' which is not dissimilar to a modern county court room. The room is lined with floor-to-ceiling bookcases covered by glass doors and containing large, hard-backed Hebrew volumes, the legal texts referred to by the Dayanim during hearings. At the top of the room the floor level is slightly raised (a step up) and contains a long table behind which are three chairs, the one in the centre a grand and large leather chair and on either side two smaller office chairs. In the centre of the room (lower level) is a conference table which can be split into smaller tables as required surrounded by eight office chairs.

The Beth Din performs a variety of different functions. The staff are asked and answer a variety of different questions concerning daily ritual and practice. The Kashrut Division of the Beth Din is the leading UK authority on Jewish Dietary Laws. ${ }^{186}$ The work of the London Beth Din sitting as a Beth Din is fourfold: the Beth Din is involved with questions concerning Jewish status, ${ }^{187}$ conversion, ${ }^{188}$ divorce ${ }^{189}$ and arbitration. ${ }^{190}$ In terms of its marriage jurisdiction, it deals with approximately 110 cases a year. Divorce constitutes

\footnotetext{
${ }^{185}$ See <http://www.theus.org.uk/the_united_synagogue/the_london_beth_din/about_us/>

${ }^{186}$ Ritual slaughter is a rabbinic rather than a Beth Din function; the Beth Din is a constituent of the Kashrut Division of the United Synagogue which licenses caterers, restaurants, factories to certify that all food ingredients are kosher. The Division operates under the aegis of The Court of the Chief Rabbi of the United Hebrew Congregations of the Commonwealth. The London Beth Din is also an authority together with two other synagogual bodies of the London Board for Shechita ritual slaughter. It is also a Kashrut authority which gives licences for bakers, caterers and manufacturers and restaurant owners.

${ }^{187}$ The London Beth Din does the majority of Orthodox conversions in Great Britain. Conversion has to be carried out through a Beth Din. The process is that the applicant studies Judaism for 1-2 years, takes part in formal lessons, is seen at regular periods (every 6 months) by a Dayan, lives within a Jewish family and learns ritual practice. The act of conversion requires circumcision for a male and for both males and females immersion in a ritual bath in the presence of three Dayanim. It has to take place in the presence of the Beth Din and also requires certification by the Beth Din.

${ }^{188}$ Jewish status is a fact, to be born of a Jewish mother. The question for this area of the Beth Din's work is whether the individual in question is Jewish or whether they will require a conversion. Status is important for synagogue membership and marriage. The Beth Din is not now directly involved with Jewish schools given that most admission policies do not hinge upon the question of being Jewish - which is a question of Jewish law. In $R$ (on the application of E) v JFS Governing Body [2009] UKSC 15 the majority of the Supreme Court held that an admissions policy which defined Jewishness in accordance with the teaching of the Office of the Chief Rabbi was a test of ethnicity and was therefore unlawful.

${ }^{189}$ Discussed below.

${ }^{190}$ It arbitration function involves it settling civil cases between private individuals or institutions in accordance with Jewish law. The arbitration function of the court mainly deals with family disputes, financial disputes, partnership disputes, employment cases and inheritance. In terms of family disputes, the Beth Din's operation as an arbitrator covers disputes about ownership or the use of property but not about divorce. In this capacity, the Beth Din operates under the Arbitration Act 1996.
} 
about twenty percent of the Beth Din's activities. The Beth Din sits three times a week throughout the year.

Although the London Beth Din is known as the Court of the Chief Rabbi, the Chief Rabbi is not personally involved in its day to day running. The Beth Din itself has no written constitution and is now a division of the United Synagogue. Its functions are spelt out as a matter of law in the contracts of the Dayanim. There are currently three full time Dayanim and one part-time Dayan. ${ }^{191}$ There is also an administrator of the Beth Din who advises the Dayanim on English law and who runs the initial stages of the arbitration process and who liaises with the United Synagogue and the Chief Rabbi. There are also three clerical staff and a Rabbi and a secretary who work on conversion clerical work for one and a half days a week. The staff are employed and funded by the United Synagogue. All of the Dayanim are Rabbis. ${ }^{192}$

The Dayanim spend a significant amount of time answering questions by Rabbis and lay people. These questions tend to relate to matters concerning daily ritual and practice. Their answers to these questions are not necessarily classified as responsa. An answer only becomes a responsum when it is written down, widely displayed and generally accepted. Some questions are relevant only to particular individuals and different answers may be given to similar questions depending upon the facts. In this role the Dayanim do not sit together as a Beth Din, but work individually in their own private offices. The Dayanim sometimes provide informal meditation or advise that parties approach the Jewish Marriage Council. The Dayanim regularly consult the authorities found in the room but in divorce cases this is usually only in relation to matters of spelling. ${ }^{193}$ Some prior cases handled in the Beth Din are persuasive but are not binding precedents as such. Lack of agreement is rare but is more common in the arbitration jurisdiction where questions of fact as well as law arise. Oaths are rarely taken. Witnesses are not required in order to corroborate evidence. ${ }^{194}$ There is no appeal.

\footnotetext{
${ }^{191}$ A Dayan (the singular form of 'Dayanim') literally means 'judge' in Hebrew.

192 The Dayanim possess formal qualifications in Jewish law required from recognised Orthodox institutions.

${ }^{193}$ See further below. They may seek opinions from other Batei Din (mainly in Israel).

${ }^{194}$ See below for a discussion of the presence of witnesses as part of the get process.
} 


\section{The Shariah Council of the Birmingham Central Mosque}

The Shariah Council and the Family Support Service share a meeting room at the Birmingham Central Mosque. This meeting room is furnished in a modern style with desks, computers and filing cabinets and obviously functions as a working office. There is a notice on the door of the room which details times at which the office was open for enquiries. On one side of the longest desk in the meeting room there are larger high backed office chairs and on the other side of the desk smaller, office chairs.

The Shariah Council has been operating for approximately ten years. It was originally set up as a personal initiative of the current chairman of the Mosque which was approved by the Central Mosque's Council of Management. ${ }^{195}$ The Council provides rulings, guidance and advice on range of issues including inheritance and requests to learn more about Islam. ${ }^{196}$ About ninety percent of the Council's time is spent dealing with marital issues. The Council attracts parties from far and wide.

Parties are originally dealt with by the Family Support Service. Two members of staff (both part time) are responsible for sifting the material or doing the preliminary work and when they reach a conclusion that the marriage is not viable or that the parties are insistent on separation or termination of the marriage the case is then put to the Shariah Council. They operate according to an unwritten code of practice. These functions have been delegated to the Family Support Service by the Shariah Council. The Shariah Council itself has four members, all of whom are volunteers. The panel is chaired by the chairman of the Mosque who is the fourth member. The members of the Council are chosen by the chairman of the Mosque on the basis of their knowledge of the Qur'an and Sunnah and also to ensure that the Council membership reflects different backgrounds. ${ }^{197}$

The Shariah Council meets monthly, usually for about three to four hours at a time.

Each case takes around five to six minutes since the preliminary work of testing whether the marriage is saveable has been done by the Family Support Service. They also give advice to the parties if there is anything which they notice that the parties should have taken into

\footnotetext{
${ }^{195}$ The Council of Management is elected every year and any major changes require the consent or sanction of the Council of Management.

${ }^{196}$ Council members are approached on matters such as conversion. Questions concerning status are dealt with by the chairman of the Mosque.

${ }^{197}$ In particular, the chairman of the Mosque is keen to select members who are not bound by a particular school of thought. No formal qualifications are necessary.
} 
account before they got married; in particular, they advise applicants who had not registered their marriages under civil law to do this next time. The Council deals with around 150 cases a year. The Council works by consensus or by majority decision in the rare case of there being a dissenting voice. No reasons for decisions are given. Prior decisions are not understood as constituting binding precedents. The parties sometimes swear an oath and occasionally they bring a representative with them. People other than the parties are occasionally called to give evidence, including children. The Council has not called any expert witnesses to date. Parties may take their case to another Shariah Council if they are unhappy with the Council's decision. ${ }^{198}$

\section{The National Tribunal for Wales in Cardiff}

Unlike the other two case studies, the National Tribunal for Wales does not have its own court room or building. Its headquarters are the House of the Archbishop in Cardiff where all archives are held. The proceedings could take place here but the Judicial Vicar has decided that they should be held in his parish Presbytery, elsewhere in Cardiff.

The National Tribunal for Wales was formed in 2007 following Vatican approval of a Decree of Erection which was jointly published by the Bishops of the three dioceses in Wales (which includes part of Herefordshire). Prior to this, Cardiff had formed a joint tribunal with West Wales. The main motivation for forming the National Tribunal for Wales was the desirability of pooling personnel. Since the Decree of Erection does not stipulate that the tribunal is a marriage tribunal, it could therefore possibly have a wider scope. Conventionally the diocesan court exercises the Bishop's judicial powers on his behalf. ${ }^{199}$ However, in practice, all of the National Tribunal's work has concerned its marriage jurisdiction.

The Archbishop of Cardiff is the Moderator of the National Tribunal. The tribunal is headed by the Judicial Vicar who is responsible for assigning the work and supervising the running

\footnotetext{
${ }^{198}$ Other Councils may come back to the original Council to verify any evidence and the Council's original decisions.

${ }^{199}$ This means that the Tribunal could determine a number of rights and duties under canon law. This could include status disputes between parishioners and their priests and other parochial disputes. However, in practice these tend to be resolved parochially. The same is true of disputes concerning finances and 'temporal goods'. (Here there is a tension between canon law and the law of England and Wales: whereas under canon law, the parish owns its own property, under charity law, the diocese is the owner.) The Tribunal could also determine disputes arising in church schools concerning the religious character of the school. The Tribunal would have no role in relation to admissions. Canon law also prescribes a recommended system of penalties for crimes. This means that the tribunal could be involved in imposing penalties for matters such as child abuse. The tribunal could impose these penalties unless the crime involved a Bishop in which case it would be dealt with by Rome.
} 
of the tribunal. The appointment of the officers is a matter for the Moderator. The National Tribunal also has an Administrator ${ }^{200}$ who ensures that the law and the procedure that the Judicial Vicar has put in place are followed. The Administrator deals with most of the correspondence and the initial applications. It is the Judicial Vicar, however, who decides whether to take the case on. Both the Judicial Vicar and the Administrator are also parish priests. Strictly, they should have Vatican approved qualifications in canon law. ${ }^{201}$ There are also two associate judicial vicars, one for each of the other two dioceses. There are six other potential judges and other personnel who fulfil the roles required under canon law such as Defender of the Bond, the Promoter of Justice, the Notary and Advocates. ${ }^{202}$ The Tribunal has no designated secretarial staff.

There is no 'hearing' as such; instead the parties are interviewed separately and given an explanation of the procedure. The parties never physically meet. The interview may take place in at the party's own home or at the Presbytery of the interviewer. The interviews of parties and witnesses are written up and are presented to the tribunal, together with pleadings by the advocate (if appointed) and defender of the bond. Expert witnesses may be sought by the judicial vicar. ${ }^{203}$ All parties swear oaths. The panel (of three) then sits in the parish Presbytery. ${ }^{204}$ Decisions are reached by majority and reasons are given. ${ }^{205}$ A judge can write a dissenting opinion which is added to the case file. The National Tribunal draws on commentaries as well as the Code of Canon $\mathrm{Law}^{206}$ and regards its own decisions and rulings from Rome as persuasive but not binding. ${ }^{207}$ Although the Code of Canon Law states that all

\footnotetext{
${ }^{200}$ Note that this title does not derive from the Code of Canon Law.

201 That is, a doctorate from Rome, Ottawa or Leuven Universities. However, those who have alternative qualifications may seek a dispensation from the Apostolic Signatura an application for a dispensation requires the candidate to submit some of their academic work for review. Dispensations are now granted for periods of three years only. In order for members of the laity to undertake roles such as Defender of the Bond they have to provide character references which document their active involvement in the Church community.

${ }^{202}$ See above.

${ }^{203}$ In some cases expert witnesses are obligatory.

${ }^{204}$ A sole judge can decide upon a case but this requires a dispensation from Rome and any appeal regarding the judgment made must be heard by a panel of three.

${ }^{205}$ Where three judges form a tribunal one is the Ponens (sentence writer). The decision of each judge is not included in the written sentence only the final judgment.

${ }^{206}$ Most notably Dignitas Connubi which expands on the Canons, provides a fuller explanation and brings common procedures together. Articles found in legal journals and opinions of eminent Canonists are also persuasive.

${ }^{207}$ However, Doe has argued that whilst theoretically there is no system of precedent in the Catholic courts, in practice some form of precedent system does exist: N Doe, "Canonical Doctrines of Judicial Precedent: A comparative study" (1994) 54 The Jurist 205-215.
} 
pastoral means should be tried to resolve a situation, ${ }^{208}$ pastoral care is left to the parish clergy. This is largely because the Tribunal will not grant an annulment unless the parties have been divorced in civil law. If the tribunal finds that the marriage is void then the case $\mathrm{e}^{209}$ is automatically passed for review to the tribunal of second instance which, in the case of Wales, is Birmingham. ${ }^{210}$

\section{Their Jurisdiction in respect of Marriage and Divorce}

This section provides a general outline of the jurisdiction each of the institutions has in relation to marriage and divorce, with particular reference to the process followed and the type of termination provided. ${ }^{211}$

\section{The Beth Din in London}

The Beth Din may occasionally, but rarely, rule on validity, but primarily deals with divorces. Its role is supervisory. The role of the Beth Din is to ensure that the parties divorce each other correctly and that the get document itself is properly drawn up. Except very rarely, the Beth Din does not judge or declare the marriage to be terminated. Usually there is no 'ruling' or judgment that the marriage has broken down, because, as with a marriage, the parties make or end the contract themselves. The function of the Beth Din is simply to witness the parties' mutual divorce and ensure, for the purposes of future remarriage and the status of future offspring of the parties within the religion, that the writing of the get document which signifies the divorce, and the procedure of handing it from the husband (or his representative) to the wife, is conducted correctly. ${ }^{212}$

A Decree Absolute under civil law is required before the get certificate is issued, though the get process itself can be completed before. The position is slightly complicated because of the provision under civil divorce law to delay the pronouncement of the decree absolute in

\footnotetext{
${ }^{208}$ Canon 1676 provides that: 'Before he accepts a case and whenever there appears to be hope of success, the judge is to use pastoral means to persuade the spouses that, if it is possible, they should perhaps validate their marriage and resume their conjugal life'.

${ }^{209}$ The Case File will contain any dissenting opinions by the judges at first instance.

${ }^{210}$ The $2^{\text {nd }}$ instance judges will not add their arguments to the case file but will issue a decree of ratification (or non-ratification) for the decree of nullity issued by the tribunal of first instance. Competence to act as a tribunal of second instance is granted by Rome.

211 The following does not go into the substantive details of the rules of the different religious faiths for terminating the marriage or declaring it void.

${ }^{212}$ For a consideration of whether the Beth Din could take a more pro-active approach, see B Jackson, Agunah: The Manchester Analysis (Deborah Charles Publishing, forthcoming 2011,).
} 
relation to these. As noted earlier in Part One of this commentary, the provision ${ }^{213}$ provides that either spouse may apply to the court for an order that a decree absolute may not be granted 'until a declaration made by both parties that they have taken such steps as are required to dissolve the marriage in accordance with [the usages of the Jews or any other prescribed religious usages] is produced to the court'.

The process falls into two stages. ${ }^{214}$ During the first stage, each spouse sees a Dayan separately to discuss their wish to end the marriage. The get process itself occurs during the second stage. For this stage, the parties are called back to the Beth Din on a separate occasion, and may attend together, or commonly, separately. If the case is straightforward, a single Dayan presides. The Dayan explains the procedure. The husband must annul any vows he may have taken not to give a get and demonstrate that he is now giving the get of his own free will. A Scribe and two appointed Witnesses ${ }^{215}$ are present whom the Husband instructs to write and sign the get. The get is then written. ${ }^{216}$ The Dayan checks that the process has been fulfilled correctly and then the husband, or his representative (again appointed by the Beth Din), hands the get to the wife declaring that she is divorced from the husband. These proceedings are not held in public. ${ }^{217}$ The fee is $£ 695$ or $£ 495$ for members of the United Synagogue.

\section{The Shariah Council of the Birmingham Central Mosque}

Over half of the cases dealt with by the Shariah Council that we studied involved couples who were not married under English civil law. The Council must be satisfied there are valid grounds for declaring the marriage over, based on evidence submitted by the applicant and in light of any conflicting evidence from the other spouse.

Given that the husband may unilaterally divorce his wife under Islamic law, it is not surprising that applicants are almost always wives. For the Shariah Council that we studied,

\footnotetext{
${ }^{213}$ Enacted by the Divorce (Religious Marriages) Act 2002 and now contained in s 10A of the Matrimonial Causes Act 1973.

${ }^{214}$ The Beth Din interviewees were keen not to see them as proceedings on the basis that fault is not being attributed.

${ }^{215}$ The 'witnesses' are not witnesses to what has gone wrong with the marriage in the way that they would be in the other tribunals, but witnesses to the giving and receiving of the get.

${ }^{216}$ The scribe writes the Get by hand which takes between one and two hours to do. After this time, the parties return to the room and are given the Get.

${ }^{217}$ The parties do not have to meet each other, but the Beth Din may appoint a representative for the husband, who hands the get to him, and he then - possibly several weeks later - hands it to the wife.
} 
the focus effectively is on determining whether the marriage is no longer workable and, as we have seen, there is a mandatory mediation stage prior to a ruling being given to see if the marriage can be saved. In essence, the Council looks to see if the marriage can be terminated by means of a talaq or khul (that is, by getting the husband to divorce the wife, or to agree to her divorcing him) and if not, it will then look for grounds to fit the circumstances of the case. Proof that the marriage is not workable any more is based on grounds which may include fault factors. Where a civil divorce has been obtained, this in itself will be taken as proof of irretrievable breakdown and as obviating the need for a religious divorce to be pronounced. Those who have entered into a civil marriage are expected to have obtained a civil divorce before seeking an Islamic divorce.

The process is threefold. First, as we have noted, the applicant or both parties will have been seen by the Family Support Service. The advisers there compile a report for the Shariah Council setting out the basis for the case. Secondly, three letters are sent out at monthly intervals inviting the husband to appear. ${ }^{218}$ Commonly, the husband does not appear. The case proceeds once the three letters have been sent. The approach is adversarial insofar as the Council is dependent upon the case and evidence presented to it by the applicant (and respondent if he appears). The Council has no facilities to call its own witnesses. The final stage is when the case goes to the Shariah Council itself. ${ }^{219}$ In the hearing itself, the parties may be represented by a solicitor, but this is very rare; more usually, an applicant may be represented by a relative (usually male) or will represent herself and may be accompanied by a relatives or friends. If, which is rare, the husband appears at the hearing, he and the wife are not heard within the Council itself at the same time, but sequentially - and so they do not have the opportunity to hear and comment directly, much less cross-examine, on what each other or any witnesses said. Nor are they necessarily informed of what the other might be saying or writing about them. The fee is $£ 150$.

\section{The National Tribunal for Wales in Cardiff}

The Roman Catholic Church may issue 'dispensations', 'dissolutions' and 'annulments'. The focus of this commentary is on the last of these, as the National Tribunal is directly

\footnotetext{
${ }^{218}$ Where the applicant has had a civil divorce then only one letter will go to the other party as a courtesy. Where there has not been a civil divorce (usually because the marriage was not registered under civil law), the three letters are sent out by recorded delivery to try to ensure that the person has received notice of the proceedings.

${ }^{219}$ Not all cases go to the Shariah Council, as sometimes people just go to the family support service for advice.
} 
concerned only with annulments. Its approach is inquisitorial: the Tribunal must be satisfied there are grounds to annul the marriage. In essence, the Tribunal is concerned with whether there was a true consent between the parties at the time of the marriage. This may be established by evidence relating to incapacity ${ }^{220}$ and several other grounds. ${ }^{221}$ The National Tribunal will not deal with an application for annulment until the civil divorce has been obtained.

The process falls into four stages. First, the applicant will approach his or her parish priest for advice (and at this stage the priest will typically explore the scope for reconciliation). The priest may ask the Advocate to speak to the applicant to give some advice, or may simply refer him or her to the Tribunal. The second stage consists of the initial application to the tribunal and an informal interview. The Tribunal Administrator sends the applicant a preliminary enquiry form to get some basic information about the spouses, and then the instructing judge or an 'auditor' 222 interviews the applicant with a view to establishing whether or not 'there is a case to answer'. ${ }^{223}$ Similarly, the respondent (if they choose to take part) will be interviewed and both parties may name witnesses to be interviewed by the tribunal. Cases may be dropped at this stage in light of the view taken by the Tribunal on the chances of success. The Tribunal is not limited to deciding on the case or evidence submitted by the parties but may proactively seek evidence, including from independent experts, on say, mental capacity: However, it does not seem that the applicant (or other party) is invited to challenge such evidence. This gathering of evidence constitutes the third stage. The fourth stage is the meeting of the tribunal itself. The tribunal ${ }^{224}$ considers all the information and opinions that have been produced to reach its verdict, which it does in private without the parties being there. The fee is $£ 450$ but may be reduced on a discretionary basis.

\footnotetext{
${ }^{220}$ For example, consanguinity, age, prior marriage, lack of mental capacity.

${ }^{221}$ Including evidence that the person suffers 'from a grave lack of discretionary judgement concerning the essential matrimonial rights and obligations to be mutually given and accepted' (Canon 1095.1.2), or 'who, because of causes of a psychological nature, [is] unable to assume the essential obligations of marriage' (Canon 1095.1.3). It is also interesting to note the concept of 'simulation', set out in Canon 1096.1: 'For matrimonial consent to exist, it is necessary that the contracting parties be at least not ignorant of the fact that marriage is a permanent partnership between a man and a woman, ordered to the procreation of children through some form of sexual cooperation'.

${ }^{222}$ A priest nominated to carry out the task.

${ }^{223}$ The interview with the instructing judge or auditor is the only direct contact the applicant will have with the panel . Even where an Advocate is appointed, he does not interview the petitioner but comments on the case that he or she has put forward.

${ }^{224}$ As explained above, the default position is that three judges should be present. However, some cases can be heard by one qualified judge.
} 


\section{Part Three: Key Findings}

\section{Introduction}

This part sets out the key findings from the project. The three case studies should not be considered to be 'typical' or 'representative' of Jewish, Christian or Islamic tribunals in general. Moreover, since our empirical investigation consisted mainly of interviews with tribunal personnel, it is important to note that the data collected derives from the perspective of the tribunal rather than of the users. ${ }^{225}$ The focus of the project was to compare the work of tribunals of different religions and how they relate to the law of the State.

The findings are organised in three sections. The first examines the organisation and operation of the tribunals in the study. The second part examines their jurisdiction in relation to marriage, nullity and divorce. The third and final section reflects upon the relationship between the tribunals and societal/civil law expectations.

\section{The Tribunals, their Structure and Sources of Authority}

\section{Diversity within Faiths}

There is no monolithic community representing the entire body within any of the three faiths we studied. Even the much greater homogeneity of the Roman Catholic Church is influenced by its local cultural and social contexts. The Catholic Church in Africa may well approach the practice of the religion differently from the Church in the USA or in Wales. And within both Islam and Judaism, there are several degrees of orthodoxy and versions of interpretation.

Similarly, there is a multiplicity of religious tribunals within the different communities in terms of the basis of their authority and adherence by those using these tribunals. Different communities within these faiths may have their own religious tribunals ruling on matters relevant to their adherents.

\footnotetext{
${ }^{225}$ There is very limited empirical research in relation to users, and this appears to be confined to shariah councils: see S Shah-Kazemi, Untying the Knot: : Muslim Women, Divorce and the Shariah (Nuffield Foundation, 2001) and S Bano, 'Islamic Family Arbitration, Justice and Human Rights in Britain', (2007) 1 Law, Social Justice \& Global Development Journal http://www.go.warwick.ac.uk/elj/lgd/2007_1/bano
} 


\section{Forum Shopping}

There is no 'hierarchy' of tribunals within the Jewish and Muslim communities, and no appeal structure. This has led to an interesting element of 'forum shopping' by litigants. The absence of a hierarchy in the Muslim and Jewish communities means that litigants can, to some extent, choose which tribunal they go to according to the way in which (they think) the law will be applied to them or by what they perceive will be the extent of recognition of the tribunal's decision across their community. While a party cannot appeal against an adverse decision, it is apparently open to a Jewish or Muslim person to make use of a different religious tribunal if they are not satisfied the first time.

This is more likely in the Muslim community, by virtue of the lack of any structural linkages between mosques according to the religious school of thought that they follow. For Jewish people, the rulings handed down by the more liberal wings of Judaism would not be recognised in the orthodox communities, so those who belong to such wings might still choose to make use of a more orthodox Beth Din in order to secure broader recognition.

The Catholic Tribunal is in a different position being part of a hierarchical appeal structure which derives its authority from Rome. However, there is still an element of 'choice' here in the form of choosing whether to pursue a remedy through the Tribunal. Indeed, it would appear that the parish priest may exercise a significant role in advising whether individuals ought to go to the Tribunal.

\section{Flexibility in use of Sources of Law and Authority}

Each religious tribunal applies a body of religious 'law' in the sense of a set of norms that are binding on adherents. However, the particular Shariah Council studied in this project appears to take a very flexible approach. It told us that it did not represent any single school of thought but rather drew on different schools of thought to arrive at what it regards as just and fair decisions. There is no system of 'precedent' which constrains its decision-making.

This is also true of the Beth Din, which will look to a range of opinions and rulings from other batei din in reaching its judgments but again, as there is no hierarchy of tribunals, it is not bound by any prior ruling. However, the particular role that the Beth Din plays in relation to divorce limits the scope for variation in any event, since Jewish divorce law as 
interpreted by this Beth Din is focused squarely on witnessing the parties' consent to divorce and is not governed by 'grounds'.

The Catholic Tribunal draws on commentaries as well as the Code of Canon Law and regards its own decisions and rulings from Rome as persuasive but not binding. This flexibility as to sources of law is common to all of the institutions we studied. The autonomous position of the particular tribunal, and/or the breadth of the rules which might be applied to the case before it, provides a degree of flexibility to the decision-maker. The institutions we studied seem to be using religious law in practical ways to meet real needs.

\section{Interaction of Religious and Legal Roles}

A commonality between all the Tribunals in relation to staffing is the degree to which their operation rests upon volunteers and the services of those who usually have other professional religious roles within their communities. There is clearly a fusion of religious and legal roles. Personnel in all three tribunals are seen as sources of guidance and advice outside the judicial process. Their authority may derive from their position in the tribunal, their standing in the community or their own personality.

None of the tribunals studied has a 'legal status' in the sense of 'recognition' by the state. They derive their authority from their religious affiliation, not from the state, and that authority extends only to those who choose to submit to them. However, as far as marriage/divorce is concerned, they are not 'arbitrators'. Their authority to rule on the validity/termination of a marriage does not derive from the parties' agreement to submit their 'dispute' to them (indeed, there may be no dispute) in the same way as an arbitration clause in a contract (for which the Beth Din and some Shariah tribunals would also qualify to rule on civil disputes). Rather, adherents to the particular faith must make use of the religious tribunal if they are to obtain sanction to remarry within their faith.

\section{Marriage, Annulment and Divorce}

\section{Grounds for Termination}

All three religions see marriage as based fundamentally on the volition of the parties. For Muslims and Jews, marriage is therefore a contract, to be ended at the parties' will. For Catholics, marriage is a sacrament as well as a contract, but the focus on a true consent as the 
basis for annulment reflects the same understanding of the essence of marriage as the other faiths.

The basis for the ending of the marriage varies as between the three tribunals. For the Shariah Council, the focus is on determining whether the marriage is no longer workable, and there is a mandatory mediation stage prior to a ruling being given to see if the marriage can be saved. It could be said that the Shariah Council has a view of the process closest to the basis of current English divorce law as both focus on whether the marriage has 'irretrievably broken down'.

For the Beth Din, no grounds need be proved, and there is no 'ruling' or judgment that the marriage has broken down. The function of the Beth Din is (in almost all cases) simply to witness the parties' mutual divorce and ensure, for the purposes of future remarriage and the status of future offspring of the parties within the religion, that the writing of the get document which signifies the divorce, and the procedure of handing it from husband to wife, are conducted correctly.

For the National Tribunal, the grounds for annulment are related to whether there was a true consent between the parties, which may be established by evidence drawn from events during the marriage itself. In this regard, some of the grounds come closer to what English law would see as voidable, rather than void, marriages, or even facts which would present as establishing irretrievable breakdown for the purposes of divorce.

\section{A Licence to Remarry}

The fundamental rationale for the grant of the religious annulment/divorce is to enable the parties to remarry within the faith. The focus is on the marriage itself, not the ancillaries (children, money and property) and reminds us that ultimately, a dissolution or annulment is a licence to remarry. For adherents, being able to remarry within the faith serves both to enable them to remain within their faith community and to regularise their position with the religious authorities. This is particularly crucial in the Jewish religion, because the failure to obtain a get will jeopardise the legitimate status of the wife's future children and descendants. 


\section{Procedure}

Process and procedure vary as between the three tribunals, reflecting the different approach to the role that each takes. For the Beth Din, there is no investigation by the tribunal into the parties' reasons for seeking a get. If there appears to be a possibility that the parties are not sure that they wish to divorce, they will be encouraged to seek counselling, but this is not part of the tribunal's function itself. Rather, the function is to supervise and witness the parties' mutual agreement that the marriage should end.

For the Shariah Council, a mediation stage is a mandatory preliminary step in the process. This is not mediation in the sense now understood in the English family justice system, which focuses on encouraging the parties to reach agreement on the consequences of the divorce. Rather, the focus is actually on reconciliation. If the applicant still wishes to proceed after mediation, the role of the Council is to ensure the marriage is unworkable and it will listen to the parties' evidence, and hear their witnesses, to arrive at its decision. The process at this stage is primarily adversarial in that the Council is in the hands of the parties as to what information is put forward to it and how arguments are presented.

The National Tribunal adopts a more proactive and inquisitorial approach in the sense that there are different individuals appointed within the process to investigate the marriage from different perspectives - in particular, the 'Defender of the Bond' explores the potential for upholding the validity of the marriage and the tribunal may seek evidence from its own witnesses, including independent experts.

None of the tribunals operates the kind of hearing common in the English civil courts (although not in the divorce court where most divorces are undefended and handled without any oral hearing) whereby both parties hear and may cross-examine on the evidence brought by the other. For the Beth Din, this is not applicable given the nature of the get process. For the National Tribunal and the Shariah Council, the parties are seen separately, although in the case of the Shariah Council, they might both be physically present on the same day for the Council to deal with their case.

All three religious tribunals are clearly aware of the emotional dimension to the process of ending a marriage and seek to recognise this by their procedures. Indeed, it might be argued that keeping the parties apart rather than hearing them at the same time is a way of doing this 
by reducing the potential for hurtful exchanges. While the Beth Din process is formal and bound by the rules regarding the writing of the get and its handing over, it provides 'helpers' to support women, and the handing over may be done by a representative rather than the husband in person. The Shariah Council appears to adopt a very informal atmosphere. The Catholic Tribunal, while bound by the canons, keeps the taking of evidence relatively informal by holding interviews with the parties and witnesses in their own localities and again, avoiding a 'hearing'. All three religious tribunals also recognise an important pastoral role in the process, either through informal advice and counselling or by encouraging parties to consult outside bodies or their own priest/rabbi/imam.

\section{Limited Role in Relation to the 'Ancillaries'}

'Ancillary' matters are those relating to the consequences of the ending of the marriage in relation to arrangements for the parties' children, or money and property. The National Tribunal has no role in relation to dealing with such consequences. Under Jewish law, it is possible for the parties to agree at the time of the marriage a) that they will agree to a get and b) that they will ask the Beth Din to resolve any ancillary disputes. Such agreements would not amount to binding arbitration contracts, since the jurisdiction of the civil courts on such matters may not be ousted by the parties' agreement (Matrimonial Causes Act 1973, s 34; Children Act 1989 s 10) and in such cases, they are advised to seek a consent order in the family courts. The Shariah Council similarly advises parties to make use of the civil courts to resolve disputes, in recognition that it cannot give legally binding rulings. However, it may advise the parties on what should be done with mahr (dower).

\section{The Relationship between the Tribunals and Societal/Civil Law Expectations}

\section{Interaction between Civil and Religious Law}

Each of the institutions firmly recognises and supports the ultimate authority of civil law processes when it comes to marriage and divorce. All three institutions encourage the parties to obtain a civil divorce, if applicable, before seeking a religious termination. Indeed, the Catholic Tribunal does not deal with an application for annulment until this has been done, and the Beth Din will not provide the certificate that a get has been given until it has proof of the civil divorce. Both the Beth Din and the Shariah Council regard the obtaining of a civil divorce as clear evidence of the parties' view that the marriage is over, and for the Shariah Council, this is conclusive, such that it does not deem it necessary to grant a religious divorce 
to enable the parties to remarry under Islamic law (although it will do so to reflect the parties' wishes for 'recognition' by the Council of the ending of their marriage).

The Beth Din considers that if the husband will not agree to a divorce, then under Jewish law, it has no means to compel him to do so. In such a case, the wife is known as a 'chained wife', or agunah. Section 10A of the Matrimonial Causes Act 1973, inserted by the Divorce (Religious Marriages) Act 2002, is intended to assist the wife by enabling the civil tribunal to withhold the grant of a decree absolute until the get has been obtained. This remedy is ineffective if the husband does not himself wish to be able to remarry under civil law since he is indifferent to whether a civil divorce is granted or not. The London Beth Din considers, however, that the legislation has reduced the number of agunot.

\section{The Place of the Religious Tribunal within the wider Society}

None of the three tribunals seeks greater 'recognition' by the state and all clearly recognise the boundaries between what they do, and the sphere of the civil courts. It is worth noting that the Divorce (Religious Marriages) Act 2002 does not 'recognise' Jewish divorce, but merely withholds the civil decree absolute in order to prompt the obtaining of such a divorce.

None of the tribunals has any legal status afforded to them by the state or the civil law, and their rulings and determinations in relation to marital status have no civil recognition either. They derive their authority from their religious affiliation, not from the state, and that authority extends only to those who choose to submit to them.

\section{Providing a Service for the Faith Community}

All of the institutions studied see their work as a religious duty. They regard themselves as providing important mechanisms for the organisation of community affairs and the fulfilment of community need. The structural framework, organisation, resourcing, and staffing of each of the tribunals in many ways reflect the history, economic resources, and social development of the communities they serve. The Beth Din, Shariah Council and Catholic Tribunal, provide an important service for those Jews, Muslims and Catholics for whom a religious divorce 'in the sight of God' is important from both a spiritual and religious legal perspective. 